\title{
Earnings Management and the Long-Run Market Performance of Initial Public Offerings
}

\author{
SIEW HONG TEOH, IVO WELCH, and T. J. WONG*
}

\begin{abstract}
Issuers of initial public offerings (IPOs) can report earnings in excess of cash flows by taking positive accruals. This paper provides evidence that issuers with unusually high accruals in the IPO year experience poor stock return performance in the three years thereafter. IPO issuers in the most "aggressive" quartile of earnings managers have a three-year aftermarket stock return of approximately 20 percent less than IPO issuers in the most "conservative" quartile. They also issue about 20 percent fewer seasoned equity offerings. These differences are statistically and economically significant in a variety of specifications.
\end{abstract}

SEVERAL STUDIES FIND THAT INITIAL public offerings (IPOs) underperform after the issue. ${ }^{1}$ Over a three-year holding period after the offering, Ritter (1991) reports substantially lower stock returns (mean of -27 percent and median of -55 percent) for a sample of 1,526 IPOs going public between 1975 and

*Teoh is at the University of Michigan, Welch is at the University of California, Los Angeles, and Wong is at the University of Science and Technology, Hong Kong. We thank Andrew Alford, Joe Aharony, John Barber, Vic Bernard, Shlomo Bernartzi, Robert Bowen, Laura Field, Steve Hansen, David Hirshleifer, Michael Kirschenheiter, Charles Lee, Tim Loughran, Susan Moyer, Gita Rao, Jay Ritter, Jake Thomas, Dan Tinkelman, Sheridan Titman, and workshop participants at the University of British Columbia, Columbia University, New York University, and the University of Washington for helpful comments. Comments received on related papers presented at the NBER 1995 Corporate Finance seminar, the 1995 CRSP Behavioral Finance conference, the 1995 Sixth Annual Finance, Economics and Accounting Conference, the 1996 AFA Conference, Ohio State University, the University of Michigan, and the University of Rochester were also helpful in shaping this paper. We thank Kent Daniel, Chris James, Mike Maher, and Jay Ritter for data. The accruals data used in this article will be made available at the Journal of Finance WWW site (http: / / www.cob.ohio-state.edu/dept/fin/journal/jof.htm) and Ivo Welch's WWW site (http://linux.agsm.ucla.edu.edu).

${ }^{1}$ For example, Stoll and Curley (1970), Stern and Borstein (1985), Ritter (1991), and Loughran and Ritter (1995) find poor subsequent performance for IPOs. Ibbotson (1975) reports statistically insignificant negative performance in the second through fourth post-issue years and positive performance in the first and fifth years. In contrast, Buser and Chan (1987) report positive performance in the first two post-issue years; Ritter (1991) discusses possible reasons for the differences in the findings. Jain and Kini (1994), Mikkelson, Partch, and Shah (1997), and Teoh, Wong, and Rao (1998) examine the accounting performance of issuers in detail. There is also now a growing literature explaining IPO stock return underperformance as related to institutional holdings (Field (1995)), venture capital (Brav and Gompers (1997)), investment banker recommendations, and analysts' characteristics (see footnote 4). 
1984 than for a size- and industry-matched sample of seasoned firms. Ritter conjectures that "investors are periodically overoptimistic about the earnings potential of young growth companies."

Our paper explores a possible source for this overoptimism. Issuers can report unusually high earnings by adopting discretionary accounting accrual adjustments that raise reported earnings relative to actual cash flows. If buyers are guided by earnings but are unaware that earnings are inflated by the generous use of accruals, they could pay too high a price. As information about the firm is revealed over time by the media, analysts' reports, and subsequent financial statements, investors may recognize that earnings are not maintaining momentum, and the investors may thus lose their optimism. Other things equal, the greater the earnings management at the time of the offering, the larger the ultimate price correction. Therefore, our study examines whether discretionary accruals predict the cross-sectional variation in post-IPO long-run stock return performance.

Our accruals variable is reported in the fiscal year when the firm goes public, which includes both pre-IPO and post-IPO months; thus, we only predict stock returns several months after this financial reporting date. The lack of readily available machine-accessible data precludes us from doing a large sample study using strictly pre-IPO data to measure earnings management. ${ }^{2}$ Because the incentives to manage earnings are likely to persist in the months immediately after the offering, we use accruals data from the first public financial statement, which includes both pre- and post-IPO months, to measure our earnings management proxy. As described in Section II, entrepreneurs usually cannot dispose of their personal holdings until at least several months after the IPO. Furthermore, firms face unusual legal and possibly reputational scrutiny in the IPO aftermath. Immediate accounting reversals may render earnings management activities transparent enough to trigger lawsuits against the firm and its management. Thus, issuers who aggressively manage their pre-IPO earnings probably also manage their first post-IPO earnings.

We relate the accruals from the first fiscal year financial statements of the IPO firm to the stock market performance from three to six months after the fiscal year end (which allows investors in the market to implement our strategy). We focus on IPO firms' current working capital accruals that are unusual when compared to industry peers (termed "discretionary"). We find that these discretionary current accruals are good predictors of subsequent three-year stock return performance in a wide variety of specifications. Depending on benchmark specification, IPO firms that are ranked in the highest quartile based on IPO-year discretionary current accruals ("aggressive"

\footnotetext{
${ }^{2}$ Two years of data are required to calculate the accruals variables, and full pre-IPO data are not always available. A large sample study, such as ours, would not be feasible using only pre-IPO data, especially for the early period of our sample. Qualitatively similar results were obtained in an earlier draft (May 1994) using pre-IPO year data to measure earnings management in a sample of 107 issuers.
} 
IPOs) earn a cumulative abnormal return of approximately 20 to 30 percent less than the cumulative abnormal return of IPO firms ranked in the lowest quartile ("conservative" IPOs). The equivalent buy-and-hold return differential between the aggressive and conservative quartiles is 15 to 30 percent.

We find that the differential performance between aggressive and conservative earnings managers is robust to a battery of alternative test specifications and controls (e.g., for market, size, book-to-market, expected return benchmark, holding period, and cumulation method effects). The discretionary current accrual effect holds for IPOs smaller than $\$ 20$ million in market capitalization (at the time of the first post-IPO financial statement, in dollars of 1997 purchasing power), for IPOs between $\$ 20$ million and $\$ 100$ million, and for IPOs larger than $\$ 100$ million. The effect is strongest in the middle category. (In order to minimize problems in implementing our investment strategies, most of our study considers only IPO firms with at least $\$ 20$ million dollars of market value at the first financial statement date after the IPO.) Although the accruals effect is stronger in some years than others, there is no clear time trend. Additional tests suggest that the ability of accruals to predict IPO stock price underperformance derives both from a general ability of accruals to predict returns in all firms and from an incremental special ability of IPO accruals to predict returns. Moreover, the former effect (general predictive ability of accruals) is more significant for IPO firms because the discretionary current accruals of IPO firms are much larger than those of average non-IPO firms. Finally, we find that managers of conservative IPO firms raise equity more frequently in the aftermarket. Of the approximately 412 IPO issuers in each quartile, 170 of the conservative quartile IPO firms (compared to 152 of the aggressive quartile IPO firms) return to the aftermarket to raise seasoned equity capital.

The rest of the paper is organized as follows. Section I describes the IPO process, and presents and motivates our measure of earnings management. Section II describes the sample selection and data. Section III shows the empirical relation between the measures of earnings management and the post-statement long-run stock price performance. Section IV tracks the post-IPO seasoned equity issuing activity of issuers. Section V concludes the paper.

\section{Earnings Management in Initial Public Offerings}

\section{A. The IPO Process}

The IPO process is particularly susceptible to earnings management, offering entrepreneurs both motivation and opportunities to manage earnings. There is high information asymmetry between investors and issuers at the time of the offering. Rao (1993) reports that there is almost no news media coverage of firms in the years before the IPO. This scarcity of information about the issuer forces investors to rely heavily on the prospectus, which itself may contain only one to three years of financial statements. 
If, as we hypothesize, investors are unable to understand fully the extent to which IPO firms engage in earnings management by borrowing from either the past or the future, high reported earnings would translate directly into a higher offering price. But the firm also has an incentive to boost earnings soon after the IPO to maintain a high market price. The original entrepreneurs may wish to sell some of their personal holdings in the secondary market at the end of the lockup period. (Entrepreneurs commit not to sell their personal holdings during a lockup period commonly lasting 180 days or longer immediately after the IPO.) Furthermore, verbal earnings projections are also made to investors during road shows at the beginning of issue marketing. ${ }^{3}$ After trading begins, security analysts initiate coverage of the firm and disseminate these earnings projections widely. To keep the aftermarket price from dropping below the initial offer price, analysts at the underwriting investment banking firms are under pressure to make the most favorable earnings projections possible. ${ }^{4}$ In turn, the issuing firm is under pressure to meet those projections in the aftermarket to safeguard its reputation for reliability; to maintain the goodwill of investors, investment bankers, and analysts who made the initial earnings projections; and to avoid lawsuits by disgruntled shareholders after a shortfall in postIPO earnings.

However, earnings are managed only if there are opportunities to do so. A key regulatory limit on entrepreneurial discretion is a requirement that accounting reports presented in the offering prospectus be audited by an external accounting firm to verify compliance with generally accepted accounting principles (GAAP). ${ }^{5}$ The "accrual accounting system" mandated by GAAP permits firms to make adjustments when reporting earnings. Managers are afforded discretion in recognizing both the timing and amounts of revenues and expenses.

These adjustments to cash flows (collectively called accruals) are supposed to reflect the underlying business condition of the firm more accurately. Though cash flows are the ultimate "bottom line" for valuation, many account-

\footnotetext{
${ }^{3}$ The prospectus of U.S. IPOs does not include earnings projections due to possible legal repercussions.

${ }^{4}$ Recent evidence (Ali (1996), Dechow, Hutton, and Sloan (1997), Lin and McNichols (1997), Michaely and Womack (1996), Rajan and Servaes (1997), Teoh and Wong (1997)) indicates that analysts are overoptimistic about new issues. Some of these papers also suggest that analysts with underwriting relationships with the issuer may be more overoptimistic than nonaffiliated analysts. Furthermore, Teoh and Wong (1997) provide evidence that analysts are insufficiently skeptical about the accruals management of new issue firms but not for the general population; the post-issue forecasts do not fully impound information in issue-year discretionary accruals for post-issue earnings.

${ }^{5}$ Our earnings management measure focuses on discretionary accounting choices and allows for either GAAP-consistent or fraudulent accounting choices. Relatively few firms are caught not complying with GAAP in the general population, and, of these, few are IPOs. Mike Maher generously provided us with the names of 159 SEC-reporting violators for the period from January 1980 to December 1985, and only six of our 485 IPO firms in this period overlapped with his sample of violators. (Three of these were caught within the first three years of the offering.)
} 
ants and market participants consider the change in cash position to be inadequate for conveying the underlying business condition, because they are influenced by the timing of cash receipts and payments from both operations and capital investment activities. However, when entrepreneurs have discretion over the accrual adjustments, it becomes difficult for investors to assess whether reported earnings in a given period are appropriate or misleading. ${ }^{6}$

Furthermore, the Accounting Principles Board Opinion 20 allows IPO firms to change their accounting choices retroactively for all the financial statements presented in the offering prospectus. This gives issuers exceptional opportunities to "doctor" their time-series profile of accounting earnings for the pre-issue fiscal years to show an increase in reported earnings.

Fear on the part of investment bankers, auditors, and entrepreneurs of becoming targets of lawsuits can also constrain firms from managing earnings. The auditor is responsible only for ensuring that the financial statements are in accordance with GAAP, and not that they are the most accurate representation of the firm's condition. (Auditors have been required to take reasonable steps to detect fraud in financial statements only since 1989 with the creation of Statement of Auditing Standards 53.) Discussions with investment bankers indicate that the underwriters' due diligence process generally does not include their own independent verification of the firm's audited financial statements. Finally, an additional constraint on earnings management comes from reputational concerns of entrepreneurs. Evidence in Section IV indicates that IPO firms that are more conservative in their financial statements appear marginally more likely to return to the capital markets for a seasoned equity offering. Thus, an enhanced ability to raise capital in the future could be either a direct or an indirect benefit to firms that manage their IPO earnings conservatively.

\section{B. Measures of Earnings Management}

Reported earnings consist of cash flows from operations and accounting adjustments called accruals. We first decompose total accruals into current and long-term components. We evaluate these two components separately because entrepreneurs have more discretion over short-term than over longterm accruals (see, e.g., Guenther (1994)). Current accrual adjustments involve short-term assets and liabilities that support the day-to-day operations of the firm. Managers can increase current accruals, for example, by advancing recognition of revenues with credit sales (before cash is received), by delaying recognition of expenses through assumption of a low provision for bad debts, or by deferring recognition of expenses when cash is advanced to suppliers. Long-term accrual adjustments, which involve long-term net as-

\footnotetext{
${ }^{6}$ For example, firms that ship products can recognize sales revenues, even if the cash payments can be delayed or if the product can be returned. Appendix B gives examples of how firms can affect reported income in detail. For the reader interested in examining a particular firm in more detail, Welch (1997) discusses one IPO firm in the apparel business that had unusually high accruals.
} 
sets, can be increased by decelerating depreciation, decreasing deferred taxes (the difference between tax expense recognized for financial reporting and actual taxes paid), or realizing unusual gains.

Not surprisingly, firms are not eager to publicize accrual adjustments that reflect their desire for a higher short-term share price rather than the economic realities of the mismatch between actual accounting events and the timing of inflows and outflows. Thus, it is difficult for investors to infer how much of the accruals are discretionary (i.e., unusual managerial choices given the underlying timing of cash flows). Given the business conditions typically faced by the firm in the industry, some accrual adjustments are appropriate and necessary, and so are expected by investors. For example, fixed-assetintensive firms have high depreciation, or rapidly growing firms may have revenues that exceed cash sales. Thus, we need a model to decompose accruals into two components, one that is dictated by firm and industry conditions and one that is presumed to be managed by the entrepreneur.

Following Teoh, Wong, and Rao (1998), we use an extension of the crosssectional Jones (1991) model for this purpose. The details of the procedure are described in Appendix A. In essence, current accruals (CA) are regressed on the change in sales in a cross-sectional regression using all firms in the same two-digit SIC code as the issuer, but excluding the issuer and other firms issuing IPO or seasoned equities within two years of the issuer. ${ }^{7}$

The cross-sectional regression is performed each fiscal year, and all variables are scaled by lagged firm assets. The fitted current accruals of the issuer are calculated using the estimated coefficients from the regression and the change in sales net of the change in trade receivables. The change in trade receivables is subtracted from the change in sales to allow for the possibility of sales manipulation. ${ }^{8}$ The fitted current accruals are considered to be the level necessary to support the firm's sales increase and is termed nondiscretionary current accruals (NDCA). The regression residual is presumed not dictated by firm and industry conditions and is considered to have been "managed," and so is termed discretionary current accruals (DCA). The cross-sectional approach automatically adjusts for the effects of fluctuating industry-wide economic conditions that influence accruals independent of any earnings management in each year. ${ }^{9}$ An equivalent procedure, in

\footnotetext{
${ }^{7}$ We exclude seasoned equity issuers in the industry Jones model regression when estimating discretionary accruals because Teoh, Welch, and Wong (1998) report earnings management prior to seasoned equity issues. An earlier version (using IPOs from 1980 through 1989) excluded only the issuer and found similar results. Also, the correlation of discretionary current accruals obtained when excluding SEOs within two years of the issuer and when just excluding contemporaneous SEO issuers is 99.9 percent.

${ }^{8}$ In other words, any sales increase that results in an increase in trade receivables is considered discretionary.

${ }^{9}$ Investment bankers also price IPOs relative to "comparable companies" in cross section. The alternative time-series approach is infeasible because IPO firms do not have a long history of financial statement data. Kim and Ritter (1998) investigate this relative IPO pricing in more detail.
} 
which total accruals are related to the change in sales as well as property, plant, and equipment (to adjust for depreciation) yields a decomposition into discretionary and nondiscretionary total accruals. The difference between discretionary total accruals and discretionary current accruals is termed discretionary long-term accruals (DLA), and the difference between nondiscretionary total accruals and nondiscretionary current accruals is termed nondiscretionary long-term accruals (NDLA).

To summarize, accruals are decomposed into four components: discretionary and nondiscretionary current accruals, and discretionary and nondiscretionary long-term accruals. Nondiscretionary accruals are the asset-scaled proxies for unmanipulated accruals dictated by business conditions. Discretionary accruals are the asset-scaled proxies for manipulated earnings determined at the discretion of management. ${ }^{10}$ Given the earlier discussion, we expect that discretionary current accruals (DCA) are the superior proxy for earnings management.

\section{Stock Prices and Earnings Management}

Our hypothesis that accounting accruals predict post-IPO stock return underperformance requires the presence of both earnings management and investor credulity. The presence of earnings management alone does not necessarily imply that IPOs are overvalued in the aftermarket. On average, negative post-IPO abnormal stock returns would not be observed if the postIPO stock market were fully efficient and we had the right model for expected returns. Investors would adequately discount the stock price to reflect earnings management observable from public information sources, and sophisticated short-selling would drive aftermarket prices quickly to an appropriate level. Our hypothesis is that the marginal investor does not rationally discount for earnings management in forming expectations about future cash flows. Ultimately, if the IPO underperformance is not merely an ex post chance event (and international and other evidence suggest it is not), it is unlikely that any fully rational theory will be able to explain why some rational investors are willing to hold IPOs in the aftermarket. Returns for what are likely to be risky and illiquid investments are simply too low to be explained by known equilibrium models. Our own evidence is consistent with a stock market for IPO firms that uses some, but not all, of the earnings information available in the financial statements. Furthermore, our evidence is consistent with managers adjusting accruals to exploit market credulity, but it does not prove that managers intentionally do so.

\footnotetext{
${ }^{10}$ High discretionary accruals may result from opportunistic overoptimistic misrepresentation of the firm's potential cash flows to influence investors, from unintentional overoptimism by the managers about future cash flows, or from timing of high accruals that the managers exploit by taking the firm public at this juncture. (We minimize the influence of the last effect by measuring discretionary accruals relative to industry peers who are likely to face similar business conditions.)
} 


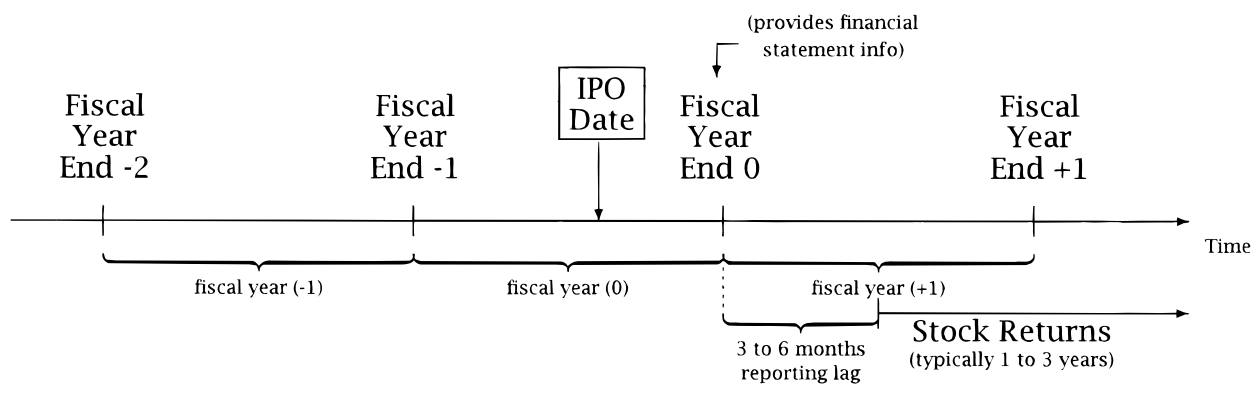

Figure 1. Time line.

\section{Sample Selection and Data}

The initial sample of domestic U.S. initial public offerings consists of 1,974 IPOs (provided to us by Chris James and Jay Ritter) for the 1980 to 1984 period, and 3,197 IPOs (obtained from Securities Data Co. (SDC)) for the 1985 to 1992 period. For inclusion in the final sample, IPOs must have available COMPUSTAT financial data both in the year of and the year prior to the offering, CRSP stock return data (at least one-month's return must be available during the three-year period beyond three months after the first fiscal year-end), an offer price exceeding one dollar, and a market capitalization of at least $\$ 20$ million in December 1997 purchasing power. These selection criteria yield a final sample size of 1,649 IPO firms. No closed-end funds (SIC code 6726) are in our final sample.

Figure 1 illustrates our timing convention. The fiscal year in which the IPO occurs is year 0 . Thus, fiscal year -1 ends before the date of the IPO, and fiscal year 0 includes both pre- and post-IPO information. Our financial statement information (e.g., discretionary current accruals, and our market capitalization screen of $\$ 20$ million) is taken from fiscal year 0 . As discussed earlier, IPO firms have an incentive to manage both pre-and immediate postIPO earnings. To allow for a reporting lag, aftermarket returns are calculated beginning three to six months (varying across specifications) after the fiscal year 0 ends. Thus, the accruals information necessary to compute our earnings management measure is available prior to the return cumulation period. This data availability constraint on the accruals forces us to examine post-issue returns beginning three to fifteen months later than the return period in other studies, which measure the post-issue stock return performance beginning after the first-day return on the issue.

Table I provides descriptive statistics for the 1,649 IPO firms in our sample. The presence of sixty-four separate two-digit SIC codes, with forty-two of these representing at least 1 percent of the sample (sixteen IPOs), indicates a wide selection of industries. Not surprisingly for our sample period, there is a concentration of IPOs in the computer and electronics industries. There is a sizeable number of IPOs in each sample year, but 1983, 1986, 1987, 1991, and 1992 are higher volume years. Oil and gas IPOs in our sample went public primarily in the first two years of our sample-declining 
oil prices in the 1980s reduced the flow of oil and gas IPOs. The sample characteristics are generally similar to those reported by Loughran and Ritter (1995), although the earlier years are undersampled due to increasing COMPUSTAT coverage of small firms over time.

Panels C and D report the IPO and immediate post-IPO characteristics that are used as control variables in our cross-sectional regression. The mean market capitalization is about $\$ 200$ million but the median is only $\$ 66$ million, both about two and one-half to three times the post-issue book values. The mean and median total assets are $\$ 277$ million and $\$ 40$ million, respectively. IPO firms experience large increases in sales as a percentage of total assets in year -1 (mean 80 percent, median 46 percent), two to three times the equivalent number for the average COMPUSTAT firm. The asset-scaled sales change is a key variable in the regression to estimate discretionary accruals. IPO firms are generally young firms, having existed for a mean of thirteen years and a median of seven years before going public. ${ }^{11}$ The offering prices average about $\$ 12.30$ per share (median $\$ 11.50$ ), and our sample IPOs are underpriced, on average, by 7 percent (median 1.6 percent). The mean (median) book-to-market ratio is 30 (40) percent, and earnings per share are 3 to 4 percent of the share price. In sum, our sample is representative of IPO firms in the sample period.

Table II, Panel A, reports the time-series distribution from the issue year to six years after for our key measure of earnings management, discretionary current accruals (DCA), and for two accounting performance measures, net income and cash flow from operations as a percentage of lagged total assets. The median discretionary current accruals decline monotonically over time from a significant positive 4.0 percent of beginning assets in the IPO year to a level insignificantly different from zero by year 3 . They then become significantly negative by year 5 and remain negative, though insignificant, in year 6.12 The time series pattern of mean accruals exhibits a similar peak in the issue year and a subsequent steady decline (the numbers are not reported in the table). The time series patterns of industry-adjusted net income and cash flow from operations also hint at earnings management. The median net income is significantly positive in year 0 and then declines monotonically to be significantly negative by year 4 . The cash flow from operations begins poorly in the issuance year and monotonically improves through year 6 . These patterns are consistent with managers advancing accruals to increase reported net income in the issuance period. Subsequently,

${ }^{11}$ We found age data for 1,601 IPOs from various sources: Jay Ritter for the early sample period, 1980 to 1984, and Securities Data Co., EDGAR and LEXIS online services, Moody's Handbook of Common Stocks, and Ward's Business Directory of US Private and Public Companies for IPOs from 1985 to 1992. Age is calculated as the number of years between IPO date and either the founding date or incorporation date, whichever is the earlier.

${ }^{12}$ We do not have data for year 6 for 1991 IPOs nor for years 5 and 6 for 1992 IPOs. The sample sizes are therefore smaller in years 5 and 6 . Moreover, poorer post-IPO performers are more likely to disappear in the later years because they may go out of business, merge, or be taken over. Because relatively more firms merge when in distress, the reported post-issue data may understate the true decline in accruals. 
Table I

\section{Sample Characteristics}

The sample consists of 1,649 domestic IPO firms going public in the period from 1980-1992 with an offering price of at least $\$ 1$ and a market capitalization of $\$ 20$ million in 1997 prices (in year 0). The sample firms must also have at least one-month post-issue stock return from CRSP beyond three months after fiscal year 0 (the fiscal year containing the issue date) and sufficient COMPUSTAT data to calculate four components of accruals in fiscal year 0 (see Appendix A for required data items). The distribution of the sample is reported in Panel A by two-digit SIC code, and in Panel B by IPO calendar year. Panel C characteristics of market value, book value of equity, total assets, and ratios $\Delta$ Sales (sales change/lagged assets), B/M (book value/market value), and $\mathrm{E} / \mathrm{P}$ (earnings/price) are measured at the end of fiscal year 0. The change in sales is from year -1 to year 0 scaled by assets in year -1 . Panel D characteristics are measured at the time of the IPO. Age is the number of years between the founding year or incorporation date (whichever is earlier) and the IPO year.

\begin{tabular}{|c|c|c|c|}
\hline \multicolumn{4}{|c|}{ Panel A: SIC Distribution } \\
\hline Industry & Two-digit SIC Codes & Freq. & $\%$ \\
\hline Oil and Gas & 13,29 & 48 & 2.9 \\
\hline Food Products & 20 & 23 & 1.4 \\
\hline Paper and Paper Products & $24-27$ & 43 & 2.6 \\
\hline Chemical Products & 28 & 140 & 8.5 \\
\hline Manufacturing & $30-34$ & 61 & 3.7 \\
\hline Computer Hardware \& Software & 35,73 & 367 & 22.3 \\
\hline Electronic Equipment & 36 & 149 & 9.0 \\
\hline Transportation & $37,39,40-42,44,45$ & 82 & 5.0 \\
\hline Scientific Instruments & 38 & 130 & 7.9 \\
\hline Communications & 48 & 41 & 2.5 \\
\hline Electric and Gas Services & 49 & 16 & 1.0 \\
\hline Durable Goods & 50 & 45 & 2.7 \\
\hline Retail & $53,54,56,57,59$ & 135 & 8.2 \\
\hline Eating and Drinking Establishments & 58 & 40 & 2.4 \\
\hline Financial Services & $61,62,64,65$ & 53 & 3.2 \\
\hline Entertainment Services & $70,78,79$ & 22 & 1.3 \\
\hline Health & 80 & 85 & 5.2 \\
\hline All others & $\begin{array}{l}1,7,10,12,15,16,17,22,23,46,47,51, \\
52,55,60,63,67,72,75,76,82,83,87,99\end{array}$ & 169 & 10.2 \\
\hline Total & & 1,649 & 100.0 \\
\hline
\end{tabular}


Panel B: Time Distribution

\begin{tabular}{|c|c|c|c|c|}
\hline Fiscal Year-End & Freq. & $\%$ & Cum. Freq. & $\%$ \\
\hline 1980 & 45 & 2.7 & 45 & 2.7 \\
\hline 1981 & 102 & 6.2 & 147 & 8.9 \\
\hline 1982 & 36 & 2.2 & 183 & 11.1 \\
\hline 1983 & 192 & 11.6 & 375 & 22.7 \\
\hline 1984 & 66 & 4.0 & 441 & 26.7 \\
\hline 1985 & 88 & 5.3 & 529 & 32.1 \\
\hline 1986 & 214 & 13.0 & 743 & 45.1 \\
\hline 1987 & 148 & 9.0 & 891 & 54.0 \\
\hline 1988 & 74 & 4.5 & 965 & 58.5 \\
\hline 1989 & 61 & 3.7 & 1,026 & 62.2 \\
\hline 1990 & 76 & 4.6 & 1,102 & 66.8 \\
\hline 1991 & 232 & 14.1 & 1,334 & 80.9 \\
\hline 1992 & 315 & 19.1 & 1,649 & 100.0 \\
\hline Total & 1,649 & $100.0 \%$ & & \\
\hline
\end{tabular}

Panel C: Post-Offering Firm Characteristics

\begin{tabular}{|c|c|c|c|c|c|c|}
\hline Units & $\begin{array}{l}\text { MV } \\
(\$ \mathrm{~m})\end{array}$ & $\begin{array}{c}\mathrm{BV} \\
(\$ \mathrm{~m})\end{array}$ & $\begin{array}{c}\mathrm{TA} \\
(\$ \mathrm{~m})\end{array}$ & $\begin{array}{c}\Delta \text { Sales } \\
(\%)\end{array}$ & $\mathrm{B} / \mathrm{M}$ & $\mathrm{E} / \mathrm{P}$ \\
\hline Mean & 199.68 & 78.68 & 276.85 & 80.47 & 0.400 & 0.032 \\
\hline Median & 66.23 & 23.06 & 39.78 & 46.30 & 0.336 & 0.042 \\
\hline
\end{tabular}

Panel D: Immediate Post-Offering Firm Characteristics

\begin{tabular}{lccc}
\hline Units & $\begin{array}{c}\text { At-IPO Firm Age } \\
\text { (years) }\end{array}$ & $\begin{array}{c}\text { Offer Price } \\
(\$)\end{array}$ \\
\hline Mean & 13.05 & 12.30 \\
Median & 7.00 & 11.50 \\
\hline
\end{tabular}


Table II

\section{Time-Series and Cross-sectional Characteristics of Discretionary}

\section{Current Accruals, the Proxy for Earnings Management}

The sample consists of 1,649 domestic IPO firms going public in the period from 1980 to 1992 with an offering price of at least $\$ 1$ and a market capitalization of $\$ 20$ million in 1997 prices (in year 0). Panel A reports time-series statistics on DCA and two accounting performance measures, net income and cash flow from operations, in percentage of lagged total assets. The accounting performance measures are relative to their two-digit industry medians, e.g., $N I_{i, t} / \mathrm{TA}_{i, t-1}-\overline{N I}_{t} / \overline{\mathrm{TA}}_{t-1}$, where $i$ indicates the firm and overlined variables are industry medians, and TA is total assets. Reported net income consists of total accruals and cash flows from operations (CFO). Accruals consist of current (working-capital) accruals (CA), the change in noncash current assets minus the change in current liabilities, and long-term accruals (LA). Discretionary current accruals (DCA) are extracted from current accruals by a within two-digit SIC industry cross-sectional modified Jones (1991) model. (See Appendix A for details of the discretionary accruals model regressions and COMPUSTAT data items for calculating accruals.) DCA measures the amount of earnings management. All accrual variables and performance measures in Panels A and B are scaled by lagged total assets and are reported as a percentage of lagged assets. $p$-values for the Wilcoxon signed-rank tests in Panel A are two-tailed. Because our COMPUSTAT data end in 1996, 1991 IPOs are included with only five years of data, and 1992 IPOs with only four years of data. Panel B reports summary statistics by issue year DCA quartile for: discretionary current accruals (always scaled by lagged assets), inflation-adjusted market capitalization $\left(\mathrm{MV}^{*}\right)$, book-to-market $(\mathrm{B} / \mathrm{M})$, earnings-to-price $(\mathrm{E} / \mathrm{P})$, and net income (NI/TA ${ }_{-1}$, scaled by lagged assets). 
Panel A: Time-Series Distribution of Accruals and Accounting Performance (as a percentage of total assets in the prior year)

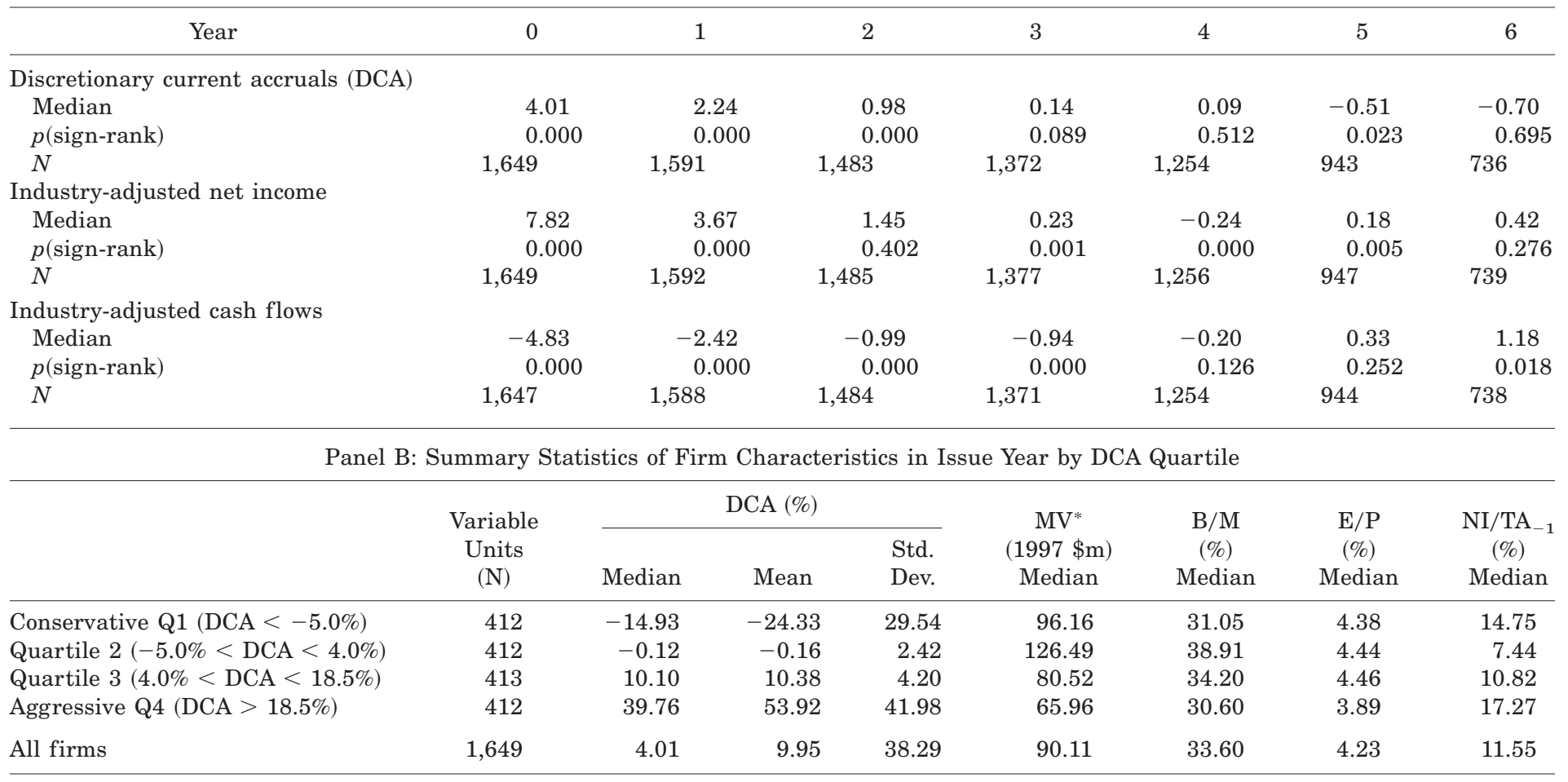


even though the median cash flow from operations actually improves every year, the decline in post-issue accruals causes a post-IPO decline in earnings. These results are consistent with Teoh, Wong, and Rao (1998), who show that these patterns are robust with respect to alternative earnings management and income performance measures.

At various points throughout the paper, we rely on a quartile classification of firms to avoid the linear parameterization of regressions. We sort the 1,649 IPO firms by their asset-scaled discretionary accruals into four quartiles, containing either 412 or 413 IPOs. We label the quartile of IPO firms with the lowest discretionary current accruals as "conservative" IPOs and the quartile of IPOs with the highest discretionary current accruals as "aggressive" IPOs. (Higher accruals increase reported earnings.) The conservative quartile has discretionary current accruals of less than -5 percent, the second quartile has accruals of -5 percent to +4 percent, the third quartile has accruals of 4 percent to 18.5 percent, and the aggressive quartile has accruals exceeding 18.5 percent.

Panel B reports sample characteristics within these quartiles. There is considerably higher cross-sectional variation within the conservative $(29.5$ percent) and aggressive quartiles (42.0 percent) than within the two middle quartiles. The overall sample standard deviation is 38.3 percent. The two quartiles with the lowest discretionary accruals contain larger firms than the two more aggressive quartiles, although this relation is not monotonic across the four quartiles. In contrast, there are no visible systematic patterns between accrual quartiles and book-to-market ratio, earnings-to-price ratio, or net income scaled by lagged assets.

We also examine the intertemporal variation in discretionary current accruals (the results are not reported in the table). We find that discretionary current accruals decline from the earlier half of the sample (pre-1987: median 5.4 percent, mean 13.1 percent) to the latter half (post-1987: median 3.1 percent, mean 7.8 percent). However, this decline over time is small compared to the within-period across-firms variation (the standard deviation of DCA is 36.4 percent pre-1987 and 39.4 percent post-1987). Furthermore, we find that the median (mean) discretionary current accruals is 3.1 percent (8.3 percent) of lagged assets in high issue volume years and 6.3 percent (13.4 percent) during other years. (Perhaps IPO investors pay less attention to post-IPO earnings when they are busy investing in other IPOs, easing the pressure for firms to manage earnings during high volume periods.) Again, this year-by-year variation is swamped by the 38 percent cross-sectional standard deviation in discretionary current accruals. Thus, the accruals effect that we document is not likely to be a mere period-specific effect.

\section{Empirical Results}

Our key objective is to evaluate the extent to which managed accruals have an influence on the long-run abnormal stock return performance of IPO firms. This requires an appropriate measure for expected long-run re- 
turns, an issue much debated in the asset pricing literature. We adopt an agnostic approach, and consider alternative measures of computing abnormal returns (buy-and-hold and cumulative abnormal returns), benchmarks (raw, market-adjusted, Fama-French (1993) adjusted, matching firms adjusted), cumulation periods, sample partitions, and regression test specifications (cross-sectional, time-series, and Fama-MacBeth (1973) type regressions). All tests indicate that discretionary current accruals reliably predict post-IPO returns.

\section{A. Distribution of Stock Returns by DCA Quartiles}

Many studies on long-run performance report buy-and-hold returns (BH), because they are most relevant for an investor. But Fama (1998) raises a set of concerns about the use of $\mathrm{BH}$ returns in long-run performance studies. In particular, buy-and-hold returns are problematic because their distribution is skewed, small initial differences can be exaggerated through compounding, and time-period overlap introduces cross-correlation problems. ${ }^{13}$ Therefore, we report both CAR and BH portfolio returns. Fama (1998) further points out that long-horizon inference can be sensitive to equilibrium expected return model specifications. ${ }^{14}$

Given the controversy about the acceptable measure for long-run performance, Panel A in Table III reports abnormal long-run returns using a variety of benchmarks. We do not report the middle quartiles both for space reasons and because quartile returns are generally monotonic. On a CAR measure, the aggressive accruals portfolio underperforms the conservative accruals portfolio by 21.6 percent in raw returns, 26.2 percent in CRSP valueweighted market-adjusted returns, and 25.4 percent in Nasdaq composite index-adjusted returns. On a $\mathrm{BH}$ measure, the underperformance is somewhat larger (24.9 percent in raw returns, 30.7 percent in CRSP marketadjusted returns, and 29.2 percent in Nasdaq-adjusted returns).

The fourth row in Panel A shows adjusted returns using the Fama and French (1993) benchmark. For each firm, returns are constrained to be

$$
R_{t}=r f_{t}+\gamma_{1}\left(M_{t}-r f_{t}\right)+\gamma_{2} S M B_{t}+\gamma_{3} H M L_{t}+A R_{t},
$$

${ }^{13} \mathrm{BH}$ and CAR standard errors are computed from the time-series of months rather than from the cross section of firms. The same month's returns for different firms enter into different event months, which could violate the uncorrelatedness assumption in time series. This problem can be addressed, for example, with a Fama and MacBeth (1973) procedure. Of course, if the equilibrium model is misspecified, even CAR standard errors, computed from the time eries, are not correct.

${ }^{14}$ Fama (1998) also criticizes long-run performance studies with no directional predictions. He notes that half of all studies seem to find underperformance, half overperformance. Our earnings management hypothesis is directional, applies both to seasoned and initial public offerings, and is present in both contexts (see Teoh, Welch, and Wong (1998) for the evidence on SEOs). 


\section{Table III}

\section{Long-Horizon Mean Abnormal Returns (in percent) by Issue Year DCA Quartiles Using}

\section{Alternative Benchmarks, Reporting Lags, and Sample Partitions.}

The sample consists of 1,649 domestic IPO firms going public in the period from 1980-1992 with an offering price of at least $\$ 1$ and a market capitalization of $\$ 20$ million in 1997 prices (in year 0). The benchmark for expected returns is the value-weighted market index in all panels except when noted otherwise in Panel A. The holding period is five to forty months after the release of the first post-IPO financial statements in all panels except when noted otherwise in Panel B. Quartile 1 firms are most conservative, quartile 4 most aggressive, in the amount of earnings management of the first post-IPO financial statements. The proxy for earnings management (discretionary current accruals, DCA) is described in Table II, and Appendix A describes the details of computing it. Cumulative abnormal returns,

$$
C A R_{T} \equiv \sum_{t=0}^{T}\left[\frac{\sum_{i=1}^{N}\left(r_{i, t}-m_{i, t}\right)}{N}\right],
$$

where $r_{i, t}$ and $m_{i, t}$ are monthly raw and benchmark returns, are statistics computed from the event time-series of firm-average monthly abnormal returns and $N$ is the number of surviving firms in month $t$. The CAR $t$-statistics have information on "bad" versus "good" event months. Buy-andhold abnormal returns,

$$
B H_{T} \equiv \frac{\sum_{i=1}^{N}\left[\prod_{t=0}^{T}\left(1+r_{i, t}\right)-\prod_{t=0}^{T}\left(1+m_{i, t}\right)\right]}{N}
$$

(when sample firm returns are missing, both $r_{i, t}$ and $m_{i, t}$ are set to zero), are statistics computed from the cross section of multimonth returns net of multimonth benchmark returns. Their $t$-statistics have information on "bad" versus "good" firms. (Due to cross-sectional correlation problems, the latter $t$-statistics should not be translated into $p$ values.)

\begin{tabular}{|c|c|c|c|c|c|c|c|c|c|c|c|}
\hline \multirow[b]{2}{*}{ Return } & \multirow[b]{2}{*}{$N$} & \multicolumn{5}{|c|}{ Cumulative Abnormal (\%) } & \multicolumn{5}{|c|}{ Buy-and-Hold (\%) } \\
\hline & & All & Q1 & $\mathrm{Q} 2$ & Q3 & Q4 & All & Q1 & $\mathrm{Q} 2$ & Q3 & Q4 \\
\hline Raw retuns & $\begin{array}{l}1,649 \\
(t \text {-stat })\end{array}$ & $\begin{array}{l}25.3 \\
(3.77)\end{array}$ & $\begin{array}{l}31.1 \\
(3.58)\end{array}$ & $\begin{array}{l}35.4 \\
(4.39)\end{array}$ & $\begin{array}{l}25.2 \\
(3.60)\end{array}$ & $\begin{array}{l}9.5 \\
(0.99)\end{array}$ & $\begin{array}{l}32.2 \\
(8.45)\end{array}$ & $\begin{array}{l}38.9 \\
(5.53)\end{array}$ & $\begin{array}{l}40.7 \\
(5.94)\end{array}$ & $\begin{array}{l}35.1 \\
(3.93)\end{array}$ & $\begin{array}{l}14.0 \\
(1.88)\end{array}$ \\
\hline $\begin{array}{l}\text { Market-adj. } \\
\text { value-weighted }\end{array}$ & $\begin{array}{l}1,649 \\
(t \text {-stat })\end{array}$ & $\begin{array}{l}-18.9 \\
(-3.79)\end{array}$ & $\begin{array}{l}-12.0 \\
(-1.60)\end{array}$ & $\begin{array}{l}-7.8 \\
(-1.24)\end{array}$ & $\begin{array}{l}-18.0 \\
(-3.19)\end{array}$ & $\begin{array}{l}-38.2 \\
(-4.85)\end{array}$ & $\begin{array}{l}-15.6 \\
(-4.12)\end{array}$ & $\begin{array}{l}-7.2 \\
(-1.04)\end{array}$ & $\begin{array}{l}-6.1 \\
(-0.90)\end{array}$ & $\begin{array}{l}-11.2 \\
(-1.26)\end{array}$ & $\begin{array}{l}-37.9 \\
(-5.13)\end{array}$ \\
\hline
\end{tabular}

Panel A: Benchmark Variations 


\begin{tabular}{|c|c|c|c|c|c|c|c|c|c|c|c|}
\hline $\begin{array}{l}\text { Market-adj. } \\
\text { Nasdaq Comp. Ind. }\end{array}$ & $\begin{array}{l}1,649 \\
(t \text {-stat })\end{array}$ & $\begin{array}{l}-13.2 \\
(-2.62)\end{array}$ & $\begin{array}{l}-5.2 \\
(-0.71)\end{array}$ & $\begin{array}{l}-4.3 \\
(-0.71)\end{array}$ & $\begin{array}{l}-13.0 \\
(-1.94)\end{array}$ & $\begin{array}{l}-30.6 \\
(-4.24)\end{array}$ & $\begin{array}{l}-7.3 \\
(-1.95)\end{array}$ & $\begin{array}{l}2.4 \\
(0.35)\end{array}$ & $\begin{array}{l}-0.7 \\
(-0.10)\end{array}$ & $\begin{array}{l}-4.1 \\
(-0.46)\end{array}$ & $\begin{array}{l}-26.8 \\
(-3.69)\end{array}$ \\
\hline Fama-French adj. & $\begin{array}{c}1,649 \\
(t \text {-stat })\end{array}$ & $\begin{array}{l}-12.1 \\
(-2.56)\end{array}$ & $\begin{array}{l}-7.4 \\
(-0.99)\end{array}$ & $\begin{array}{l}-2.6 \\
(-0.50)\end{array}$ & $\begin{array}{l}-12.3 \\
(-2.01)\end{array}$ & $\begin{array}{l}-26.4 \\
(-3.55)\end{array}$ & $\begin{array}{l}-6.3 \\
(-1.78)\end{array}$ & $\begin{array}{l}0.7 \\
(0.11)\end{array}$ & $\begin{array}{l}2.0 \\
(0.31)\end{array}$ & $\begin{array}{l}-4.7 \\
(-0.56)\end{array}$ & $\begin{array}{l}-23.2 \\
(-3.34)\end{array}$ \\
\hline Matching firm adj. & $\begin{array}{c}1,649 \\
(t \text {-stat })\end{array}$ & $\begin{array}{l}-8.7 \\
(-2.35)\end{array}$ & $\begin{array}{l}-2.0 \\
(-0.29)\end{array}$ & & & $\begin{array}{l}-27.5 \\
(-3.60)\end{array}$ & $\begin{array}{l}0.5 \\
(0.11)\end{array}$ & $\begin{array}{l}13.5 \\
(1.62)\end{array}$ & & & $\begin{array}{l}-25.0 \\
(-2.39)\end{array}$ \\
\hline \multicolumn{12}{|c|}{ Panel B: Holding Period Variations, Value-Weighted Market-Adjusted Benchmark } \\
\hline $\begin{array}{l}\text { Sooner } \\
\quad+3 \ldots+38\end{array}$ & $\begin{array}{l}1,649 \\
(t \text {-stat })\end{array}$ & $\begin{array}{l}-21.4 \\
(-4.74)\end{array}$ & $\begin{array}{l}-12.1 \\
(-1.67)\end{array}$ & $\begin{array}{l}-10.6 \\
(-1.84)\end{array}$ & $\begin{array}{l}-20.6 \\
(-3.77)\end{array}$ & $\begin{array}{l}-42.8 \\
(-5.55)\end{array}$ & $\begin{array}{l}-18.3 \\
(-5.13)\end{array}$ & $\begin{array}{l}-5.7 \\
(-0.82)\end{array}$ & $\begin{array}{l}-9.4 \\
(-1.47)\end{array}$ & $\begin{array}{l}-17.0 \\
(-2.20)\end{array}$ & $\begin{array}{l}-41.0 \\
(-5.64)\end{array}$ \\
\hline $\begin{array}{l}\text { Later } \\
\quad+7 \ldots 42\end{array}$ & $\begin{array}{c}1,649 \\
(t \text {-stat })\end{array}$ & $\begin{array}{l}-17.4 \\
(-3.39)\end{array}$ & $\begin{array}{l}-11.6 \\
(-1.53)\end{array}$ & $\begin{array}{l}-5.7 \\
(-0.90)\end{array}$ & $\begin{array}{l}-16.2 \\
(-2.75)\end{array}$ & $\begin{array}{l}-36.5 \\
(-4.52)\end{array}$ & $\begin{array}{l}-14.6 \\
(-3.72)\end{array}$ & $\begin{array}{l}-6.7 \\
(-0.90)\end{array}$ & $\begin{array}{l}-5.5 \\
(-0.85)\end{array}$ & $\begin{array}{l}-10.8 \\
(-1.21)\end{array}$ & $\begin{array}{l}-35.4 \\
(-4.24)\end{array}$ \\
\hline $\begin{array}{l}\text { Longer* }^{*} \\
\quad+5 \ldots+52\end{array}$ & $\begin{array}{c}1,649 \\
(t \text {-stat })\end{array}$ & $\begin{array}{l}-22.6 \\
(-3.92)\end{array}$ & $\begin{array}{l}-11.8 \\
(-1.47)\end{array}$ & $\begin{array}{l}-7.9 \\
(-1.01)\end{array}$ & $\begin{array}{l}-23.6 \\
(-3.16)\end{array}$ & $\begin{array}{l}-47.6 \\
(-4.96)\end{array}$ & $\begin{array}{l}-21.1 \\
(-4.14)\end{array}$ & $\begin{array}{l}-7.0 \\
(-0.72)\end{array}$ & $\begin{array}{l}-6.7 \\
(-0.61)\end{array}$ & $\begin{array}{l}-14.4 \\
(-1.22)\end{array}$ & $\begin{array}{l}-56.1 \\
(-7.61)\end{array}$ \\
\hline \multicolumn{12}{|c|}{ Panel C: Sample Partitions, Value-Weighted Market Adjusted Benchmark } \\
\hline \multicolumn{12}{|c|}{ By firm size in real 1997 dollars } \\
\hline $\begin{array}{l}\text { Tiny firms* } \\
<\$ 20 \mathrm{~m}\end{array}$ & $\begin{array}{c}509 \\
(t \text {-stat })\end{array}$ & $\begin{array}{l}-18.9 \\
(-2.23)\end{array}$ & $\begin{array}{l}-21.8 \\
(-1.64)\end{array}$ & $\begin{array}{l}-7.7 \\
(-0.44)\end{array}$ & $\begin{array}{l}-18.6 \\
(-1.23)\end{array}$ & $\begin{array}{l}-28.1 \\
(-2.00)\end{array}$ & $\begin{array}{l}-31.6 \\
(-4.91)\end{array}$ & $\begin{array}{l}-17.3 \\
(-1.14)\end{array}$ & $\begin{array}{l}-28.5 \\
(-2.29)\end{array}$ & $\begin{array}{l}-31.6 \\
(-2.62)\end{array}$ & $\begin{array}{l}-48.7 \\
(-4.22)\end{array}$ \\
\hline $\begin{array}{l}\text { Medium-size firms } \\
\$ 20 \mathrm{~m} \text { to } \$ 100 \mathrm{~m}\end{array}$ & $\begin{array}{c}888 \\
(t \text {-stat })\end{array}$ & $\begin{array}{l}-25.2 \\
(-4.01)\end{array}$ & $\begin{array}{l}-17.6 \\
(-1.81)\end{array}$ & $\begin{array}{l}-11.4 \\
(-1.30)\end{array}$ & $\begin{array}{l}-21.5 \\
(-3.26)\end{array}$ & $\begin{array}{l}-44.1 \\
(-4.37)\end{array}$ & $\begin{array}{l}-21.9 \\
(-4.10)\end{array}$ & $\begin{array}{l}-4.6 \\
(-0.42)\end{array}$ & $\begin{array}{l}-11.8 \\
(-1.03)\end{array}$ & $\begin{array}{l}-14.0 \\
(-1.13)\end{array}$ & $\begin{array}{l}-49.4 \\
(-6.18)\end{array}$ \\
\hline $\begin{array}{l}\text { Large firms } \\
\quad>\$ 100 \mathrm{~m}\end{array}$ & $\begin{array}{c}761 \\
(t \text {-stat })\end{array}$ & $\begin{array}{l}-11.6 \\
(-2.43)\end{array}$ & $\begin{array}{l}-5.8 \\
(-0.69)\end{array}$ & $\begin{array}{l}-5.0 \\
(-0.82)\end{array}$ & $\begin{array}{l}-13.7 \\
(-2.22)\end{array}$ & $\begin{array}{l}-27.4 \\
(-2.76)\end{array}$ & $\begin{array}{l}-8.2 \\
(-1.55)\end{array}$ & $\begin{array}{l}-10.0 \\
(-1.21)\end{array}$ & $\begin{array}{l}-1.8 \\
(-0.22)\end{array}$ & $\begin{array}{l}-7.7 \\
(-0.61)\end{array}$ & $\begin{array}{l}-16.8 \\
(-1.14)\end{array}$ \\
\hline \multicolumn{12}{|l|}{ By book-to-market ratio } \\
\hline $\begin{array}{l}\text { "Growth" } \\
<0.3\end{array}$ & $\begin{array}{c}817 \\
(t \text {-stat })\end{array}$ & $\begin{array}{l}-23.4 \\
(-3.92)\end{array}$ & $\begin{array}{l}-14.7 \\
(-2.08)\end{array}$ & $\begin{array}{l}-5.1 \\
(-0.57)\end{array}$ & $\begin{array}{l}-14.7 \\
(-1.79)\end{array}$ & $\begin{array}{l}-54.5 \\
(-4.92)\end{array}$ & $\begin{array}{l}-16.2 \\
(-2.76)\end{array}$ & $\begin{array}{l}-15.5 \\
(-1.83)\end{array}$ & $\begin{array}{l}-2.2 \\
(-0.22)\end{array}$ & $\begin{array}{l}-0.9 \\
(-0.06)\end{array}$ & $\begin{array}{l}-40.9 \\
(-3.56)\end{array}$ \\
\hline $\begin{array}{c}\text { "Value" } \\
>0.3\end{array}$ & $\begin{array}{c}832 \\
(t \text {-stat })\end{array}$ & $\begin{array}{l}-14.5 \\
(-2.66)\end{array}$ & $\begin{array}{l}-8.9 \\
(-0.87)\end{array}$ & $\begin{array}{l}-9.6 \\
(-1.52)\end{array}$ & $\begin{array}{l}-20.9 \\
(-3.05)\end{array}$ & $\begin{array}{l}-18.9 \\
(-1.97)\end{array}$ & $\begin{array}{l}-14.9 \\
(-3.13)\end{array}$ & $\begin{array}{l}2.9 \\
(0.26)\end{array}$ & $\begin{array}{l}-8.8 \\
(-0.96)\end{array}$ & $\begin{array}{l}-20.5 \\
(-2.30)\end{array}$ & $\begin{array}{l}-34.2 \\
(-4.00)\end{array}$ \\
\hline \multicolumn{12}{|l|}{ By subperiods } \\
\hline $\begin{array}{l}\text { First half } \\
1980 \text { to } 1986\end{array}$ & $\begin{array}{c}662 \\
(t \text {-stat })\end{array}$ & $\begin{array}{l}-34.7 \\
(-5.01)\end{array}$ & $\begin{array}{l}-31.7 \\
(-3.55)\end{array}$ & $\begin{array}{l}-20.1 \\
(-2.29)\end{array}$ & $\begin{array}{l}-31.9 \\
(-3.41)\end{array}$ & $\begin{array}{l}-49.6 \\
(-4.42)\end{array}$ & $\begin{array}{l}-40.1 \\
(-9.41)\end{array}$ & $\begin{array}{l}-26.9 \\
(-2.93)\end{array}$ & $\begin{array}{l}-26.7 \\
(-3.33)\end{array}$ & $\begin{array}{l}-42.9 \\
(-6.36)\end{array}$ & $\begin{array}{l}-57.8 \\
(-6.41)\end{array}$ \\
\hline $\begin{array}{l}\text { Second half } \\
1987 \text { to } 1992\end{array}$ & $\begin{array}{c}987 \\
(t \text {-stat })\end{array}$ & $\begin{array}{l}-8.5 \\
(-1.38)\end{array}$ & $\begin{array}{l}-0.0 \\
(-0.00)\end{array}$ & $\begin{array}{l}-1.2 \\
(-0.14)\end{array}$ & $\begin{array}{l}-9.9 \\
(-1.44)\end{array}$ & $\begin{array}{l}-26.9 \\
(-2.54)\end{array}$ & $\begin{array}{l}0.8 \\
(0.15)\end{array}$ & $\begin{array}{l}5.1 \\
(0.54)\end{array}$ & $\begin{array}{l}5.0 \\
(0.53)\end{array}$ & $\begin{array}{l}8.8 \\
(0.64)\end{array}$ & $\begin{array}{l}-19.0 \\
(-1.67)\end{array}$ \\
\hline
\end{tabular}

*Four-year holding periods and IPO firms with less than $\$ 20$ million (in 1997 dollars) are not used elsewhere in the paper. 
where $t$ is an event month index, $R_{t}$ is the raw return for one firm, $r f_{t}$ is the risk-free rate, $M_{t}$ is the value-weighted market return, $S M B_{t}$ is the return difference between a portfolio of small and a portfolio of large firms, and $H M L_{t}$ is the return difference between a portfolio of high book-to-market and a portfolio of low book-to-market firms. ${ }^{15}$

Both the returns and exposure coefficients for IPO firms may be unreliable because 8 percent of the firms disappear within 36 months. When there are fewer than twelve monthly return observations-too few to reliably estimate gamma coefficients-we compute abnormal return $(A R)$ as a marketadjusted return $\left(A R_{i, t}=v R_{i, t}-M_{i, t}\right)$ instead of the Fama-French abnormal return (from equation (1)) for this particular firm. The Fama-French procedure suggests a smaller underperformance differential of 19.0 percent on a CAR basis and 23.9 percent on a $\mathrm{BH}$ basis.

The fifth row of Panel A adjusts returns using a set of matched firms as benchmark. Following Ritter's (1991) procedure, each IPO firm is matched with a nonissuing firm from CRSP based on industry membership and market capitalization. (Firms issuing seasoned equity are included as potential matches.) If the original matched firm drops out before the IPO firm, the next best match as of the original match date is spliced in for the remainder of the cumulation period to avoid survivorship bias in the matched sample. If the sample firm drops out, both sample and matching firms are assigned zero returns for the remainder of the period. Barber and Lyon (1997) report that this procedure is reasonably reliable. The matched-firm benchmark suggests a performance differential between aggressive and conservative accruers of 25.5 percent on a CAR measure and 38.5 percent on a $\mathrm{BH}$ measure. In sum, the long-run performance differential between aggressive and conservative earnings managers seems large and economically significant regardless of the benchmark used.

For brevity, the remainder of Table III reports only the value-weighted market-adjusted returns. Panel B shows that varying the starting months by either +2 or -2 months does not substantially impact our results. Neither variation changes the conclusions. The third row extends the holding period from three to four years. Conservative quartile firms have stabilized after three years (as have the unreported quartiles 2 and 3), but the aggressive quartile firms continue to deteriorate another 11.1 percent in CAR terms, and 20.7 percent in $\mathrm{BH}$ terms in the fourth year. (We do not use four-year returns elsewhere in the paper.)

Panel C considers sample partitions by size, book-to-market ratios, and time-period. The size partition is based on market capitalization measured at the time of the first financial statement post-IPO with cutoffs at $\$ 20$ million and $\$ 100$ million (in December 1997 real dollars). The differential in returns between aggressive and conservative quartiles is apparent within all size subgroups. The 509 small firms $(<\$ 20 \mathrm{~m})$ have the smallest CAR differential (6.3 percent; $\mathrm{BH}=31.4$ percent); the 761 large firms $(>\$ 100 \mathrm{~m})$

\footnotetext{
${ }^{15}$ Gene Fama and Ken French generously provided us with their factor returns.
} 
have the smallest $\mathrm{BH}$ differential $\left(6.8\right.$ percent; ${ }^{16} \mathrm{CAR}=21.6$ percent). The largest differentials between aggressive and conservative firms (illustrating the strongest accruals effect) occur in the 888 middle-sized firms: 26.5 percent in CAR terms and 44.8 percent in $\mathrm{BH}$ terms. (Within-size quartile differences are explored further in Appendix C, Table AI.)

The next partition by market-to-book ratio uses a cutoff of 30 percent. Again, in both subsamples, aggressive firms underperform conservative firms. There is no distinct pattern in whether value firms or growth firms display a greater differential. The final sample partition (by time period) shows that the aggressive versus conservative stock return differential increases from 17.9 percent pre- 1987 to 26.9 percent post-1987 on a CAR basis. On a BH basis, the differential decreases from 30.9 percent pre-1987 to 24.1 percent post-1987. More detailed (unreported) investigations show that the differential is strong in seven of twelve years (including 1992), weak in four years (including 1990 and 1991), and reverses in 1988 when there were relatively few IPOs following the 1987 stock market crash. The small number of observations per year renders definite statements about time trends in the effect of discretionary accruals on later returns unreliable.

In sum, even if inferences on the magnitude of IPO long-run underperformance are sensitive to the abnormal return computation, the difference in performance between firms employing different degrees of earnings management is not. More conservative firms outperform more aggressive firms by a margin that is economically significant.

Figure 2 plots the time series of buy-and-hold returns of the four quartile portfolios (plus the overall average) net of the Nasdaq composite index benchmark buy-and-hold returns. The figure shows that IPO firms in the conservative first quartile outperform the Nasdaq market by about 4 percent over three years, whereas the aggressive fourth quartile IPO firms underperform by about 25 percent. (Composed of many new IPOs and small firms itself, the Nasdaq index performed relatively poorly throughout the sample period, so the magnitude of IPO underperformance indicated by this benchmark is relatively conservative. As noted previously, our focus is on explaining the cross-sectional variation in the underperformance with our accruals measure, and not on the magnitude of the underperformance per se. The cumulated returns of the aggressive and conservative quartiles display a different drift if another benchmark is used, but the return differential itself is robust with respect to alternative benchmarks.) The figure also shows that nonconservative portfolios deteriorate in the first twelve months, with the aggressive quartile 4 portfolio (and then the quartile 3 portfolio) performing worst. During the years thereafter, the nonaggressive portfolios show only a small drift, but the most aggressive quartile 4 portfolio enjoys only a six-month reprieve before resuming its dramatic decline.

\footnotetext{
16 The unreported next conservative quartile 2 shows a $\mathrm{BH}$ underperformance of 1.8 percent, the unreported next aggressive quartile 3 shows a $\mathrm{BH}$ underperformance of 7.7 percent. We do not use these smallest firms elsewhere in the paper.
} 


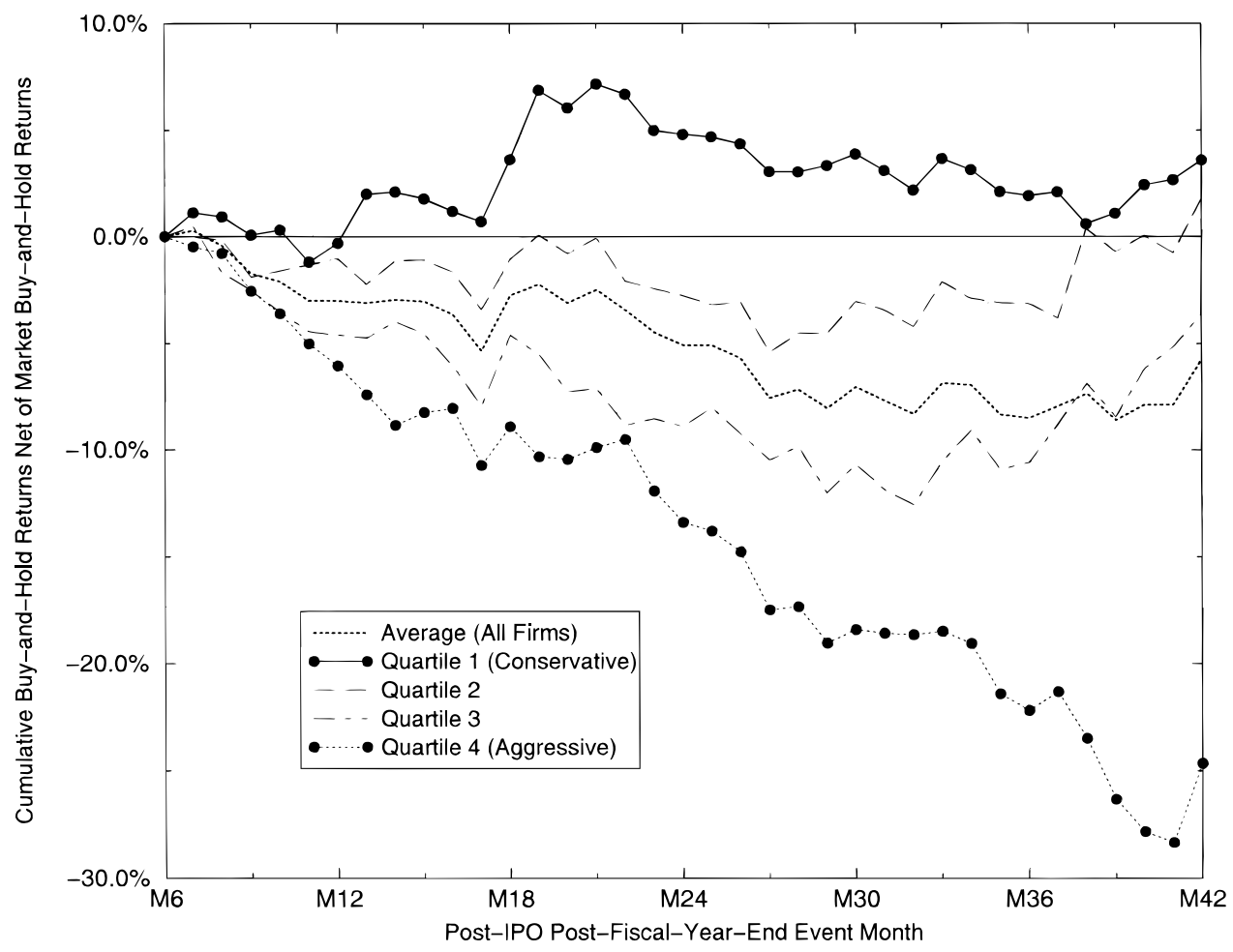

Figure 2. Cumulative buy-and-hold return net of Nasdaq composite index return of DCA quartiles by event month, in percent. The sample is of 1,649 IPOs from the 1980-92 period. (Details are described in Table I.) Firms are divided into quartiles based on how aggressively they manage their earnings. Our measure of earnings management is the firm's discretionary current accruals (DCA), which adjusts for industry, size, and growth. Details are described in Table II and Section I.B.

\section{B. Event-Time Cross-Sectional Regressions}

To examine the incremental influence of the accrual variables on postissue stock return underperformance, we add the four accrual variables to the regression in Ritter (1991, Table X). The IPO three-year post-issue buyand-hold returns are regressed on the four accrual variables and a set of control variables for other known potential predictors in one cross-sectional regression. The control variables are year-dummies (coefficients are not reported; these subsume the year-issuing-volume measure in Ritter (1991)); a contemporaneous three-year value-weighted buy-and-hold market return from the exchange that listed the IPO (MktRet); the IPO firm's logged capitalization at December 1997 prices $\left(\mathrm{MV}^{*}\right)$ and logged book-to-market ratio (BV/ MV); the IPO first-day underpricing return (Underpr); one high-tech (HiTech) and one oil\&gas (Oil\&Gas) industry dummy; one plus the log of the firm's age (AGE); lagged asset-scaled mean capital expenditure, $\Delta$ CapExp, mea- 
sured as asset-scaled mean capital expenditures in years 1, 2, and 3 less the asset-scaled mean capital expenditure in years -1 and 0 ; and the assetscaled net income growth, $\Delta$ NetIncome in the IPO year. ${ }^{17}$ Although such regressions ignore the contemporaneous correlations among variables, and can lead to biased standard errors (but not biased coefficient estimates), Ritter's results have been supported in other studies. Furthermore, this specification provides regression coefficients that allow an easy interpretation of the economic significance. The estimated regression is

$$
\begin{aligned}
R_{i}= & \alpha_{0}+\sum_{k=81}^{92} \cdot \alpha_{k} \operatorname{Yr}(k) \\
& -0.227^{* *} \cdot \mathrm{DCA}_{i}+0.053 \cdot \mathrm{DLA}_{i}-0.241 \cdot \mathrm{NDCA}_{i}-0.004 \cdot \mathrm{NDLA}_{i} \\
& +1.000^{* * *} \cdot \mathrm{MktRet}_{i}+0.020 \cdot \log \left(\mathrm{MV}^{*}\right)_{i}+0.264 \cdot \log (\mathrm{BV} / \mathrm{MV})_{i} \\
& +0.020 \cdot \mathrm{Underpr}_{i}-0.717^{* * *} \cdot \mathrm{Oil}_{\mathrm{Gas}}+0.095 \cdot \mathrm{HiTech}_{i} \\
& +0.007 \cdot \log \left(1+\mathrm{AGE}_{i}+1.124^{* * *} \cdot \Delta \mathrm{CapExp}_{i}\right. \\
& +0.217^{* * *} \cdot \Delta \mathrm{NetIncome}_{i}+\epsilon_{i},
\end{aligned}
$$

where $R_{i}$ is the three-year post-issue buy-and-hold return calculated starting four months after the first fiscal year-end, and the independent variables include the four accruals and controls. Three stars denote significance at the 1 percent level (if residuals are uncorrelated). The regression statistics show that the regression is adequately specified. The $F$-statistic for regression fit is highly significant, the adjusted $R$-square of the regression is 6.37 percent, and the chi-square test indicates no significant heteroskedasticity in the regression residuals.

The key variable, discretionary current accruals (DCA), has a significantly negative estimated coefficient of -0.227 ( $p$-value 0.03 ), indicating that firms with high earnings management proxy to boost earnings in the year of the IPO subsequently show greater underperformance. With a mean (median) discretionary current accrual spread of about 78 percent (55 percent) between quartiles 1 and 4 , the estimated coefficient on DCA implies a return difference of 17.7 percent (12.5 percent using the median) between the extreme quartiles. The estimated DCA coefficient increases when the regression specification is estimated without extreme observations of DCA (not reported). For example, truncating the sample at the 1st and 99th per-

${ }^{17} \Delta$ CapExp, which controls for Cheng's (1995) documented mean effect, shows strong significance in our IPO sample, perhaps because it is measured using post-issue data and so has a large timing advantage relative to the other variables. $\Delta$ NetIncome measures the incremental effect of the accrual variables over an income growth variable. Thus, significance of the accrual variables suggests that investors are credulous with respect to the accruals component and not just merely to income growth. 
centiles increases the estimated DCA coefficient to -0.573 ( $p$-value 0.000 , $t$-statistic of -4.008). Thus, a one-standard deviation increase in DCA (about 28.8 percent in the truncated sample) implies a 16.5 percent return difference. Finally, among the four accrual variables, only the DCA variable is consistently robust across a variety of alternative regression specifications. ${ }^{18}$

\section{Time-Series Regressions Using Book-to-Market and Market Capitalization Adjusted Returns}

We vary the test specification in this subsection by using a calendar timeseries approach (shown to be reliable for random samples by Lyon, Barber, and Tsai (1998)) and a novel portfolio membership selection procedure that controls for size and book-to-market effects. We construct two portfolios that differ in their discretionary current accruals, but not in their size and bookto-market characteristics. We then compare their estimated intercepts in a regression of portfolio returns on the Fama-French (1993) three-factor returns in Table IV,

$$
R_{p t}-R_{f t}=a+b \cdot\left(R_{m t}-R_{f t}\right)+s \cdot S M B_{t}+h \cdot H M L_{t}+\epsilon_{t},
$$

where $t$ is a calendar (not event!) month index; $R_{p t}$ is the relevant conservative or aggressive DCA portfolio return adjusted for size and book-to-market differences to be explained below; $R_{m t}$ is the return on the value-weighted CRSP index; $R_{f t}$ is the beginning-of-month three-month T-bill yield; $S M B_{t}$ is the return on small firms minus the return on large firms; and $H M L_{t}$ is the return on high book-to-market stocks minus the return on low book-tomarket stocks (see Fama and French (1993)). IPO firm returns are included in the portfolio returns only for the period from four to thirty-nine months after the IPO fiscal year-end. If the Fama-French return model is an appropriate expected return model, the intercepts are expected to be zero if DCA has no effect. Thus, any remaining significant differences between intercepts of the two portfolios can be ascribed to differences in DCA.

To ensure minimal differences in size and in book-to-market while maintaining sufficient difference in discretionary current accruals between the portfolios, we sort IPO firms into two portfolios. For the size-adjusted portfolio regressions, all IPO firms are first ranked by market capitalization at the end of the issue fiscal year (adjusted to December 1997 prices). Then, from each contiguous set of four IPO firms, we place the IPO firm with the highest DCA into an aggressive DCA portfolio, and the IPO firm with the lowest DCA into a conservative DCA portfolio. Since contiguous size-ranked

\footnotetext{
${ }^{18}$ A previous draft of our paper reports robustness of results for a sample of 1980 to 1989 IPOs when ranked variable regressions are used and when IPOs are eliminated if the Jones (1991) industry cross-sectional regression coefficients are negative. For our current sample, the estimated coefficient and significance of the DCA variable are higher when we include IPO firms with less than $\$ 20$ million in the regression (without sample truncation).
} 


\section{Table IV}

\section{Fama-French Three-Factor Monthly Return Time Series Regressions for Size and Book-to-Market Equivalent Conservative and Aggressive (DCA) Portfolios}

The sample consists of 1,649 domestic IPO firms going public in the period from 1980 to 1992 with an offering price of at least $\$ 1$ and a market capitalization of $\$ 20$ million in 1997 prices (in year 0 ). The table presents time-series regression coefficients from

$$
R_{p t}-R_{f t}=a+b \cdot\left(R_{m t}-R_{f t}\right)+s \cdot S M B_{t}+h \cdot H M L_{t}+\epsilon_{t},
$$

where $R_{p t}$ are the value-weighted or equally weighted returns of the aggressive and conservative portfolios in calendar month $t ; R_{m t}$ is the return on the value-weighted CRSP index in month $t ; R_{f t}$ is the beginningof-month three-month T-bill yield in month $t ; S M B_{t}$ is the return on small firms minus the return on large firms in month $t ; H M L_{t}$ is the return on high book-to-market stocks minus the return on low book-to-market stocks in month $t$ (see Fama and French (1993)). Firms are considered IPOs from the fourth to the thirtyninth month after the first fiscal year-end. IPO firms in the aggressive and conservative discretionary current accrual (see Table II) portfolios are selected to minimize size and book-to-market differences in the following way. For minimizing size differences, all IPO firms are first ranked by market capitalization at the end of the issue fiscal year adjusted to December 1997 prices. Then, for each contiguous group of four IPO firms, the firm with the largest DCA is placed into an aggressive portfolio and the firm with the lowest DCA is placed into a conservative DCA portfolio. The book-to-market adjustment is done similarly by first ranking all IPO firms by their issue year-end book-to-market ratios. The $t$-statistic in the table is from the intercept in an (unreported) equivalent regression of the difference between the conservative and aggressive portfolio returns on the factor returns.

\begin{tabular}{|c|c|c|c|c|c|}
\hline & \multirow[b]{2}{*}{ Statistic } & \multicolumn{2}{|c|}{ Similar MV* } & \multicolumn{2}{|c|}{ Similar BV/MV } \\
\hline & & Conservative & Aggressive & Conservative & Aggressive \\
\hline \multicolumn{6}{|c|}{ Panel A: Value-Weighted Portfolio Returns (in percent) } \\
\hline \multirow[t]{2}{*}{$\bar{a}$} & Coef & 0.052 & $-0.658^{* *}$ & 0.078 & $-0.554^{*}$ \\
\hline & $p$-val & 0.839 & 0.032 & 0.807 & 0.058 \\
\hline \multirow[t]{2}{*}{$b$} & Coef & $0.997^{* * *}$ & $1.062^{* * * *}$ & $0.885^{* * *}$ & $1.120^{* * * * *}$ \\
\hline & $p$-val & 0.000 & 0.000 & 0.000 & 0.000 \\
\hline \multirow[t]{2}{*}{$s$} & Coef & $0.547^{* * *}$ & $0.556^{* * * *}$ & $0.441^{* * * *}$ & $0.947^{* * * *}$ \\
\hline & $p$-val & 0.000 & 0.000 & 0.001 & 0.000 \\
\hline \multirow[t]{3}{*}{$h$} & Coef & $-0.423^{* * *}$ & $-0.342^{* *}$ & $-0.602^{* * *}$ & $-0.409^{* * *}$ \\
\hline & $p$-val & 0.000 & 0.016 & 0.000 & 0.000 \\
\hline & $\bar{R}^{2}$ & 0.735 & 0.674 & 0.614 & 0.748 \\
\hline \multirow{2}{*}{\multicolumn{2}{|c|}{$\begin{array}{l}a(\text { Aggressive })-a(\text { Conservative }) \\
t \text {-statistic }\end{array}$}} & \multicolumn{2}{|c|}{$-0.710^{* *}$} & \multicolumn{2}{|c|}{$-0.634^{*}$} \\
\hline & & \multicolumn{2}{|c|}{-2.165} & \multicolumn{2}{|c|}{-1.701} \\
\hline \multicolumn{2}{|c|}{ Two-tailed $P$-value } & & & & \\
\hline & $N$ & \multicolumn{4}{|c|}{156 months: January 1983-December 1995} \\
\hline \multicolumn{6}{|c|}{ Panel B: Equally Weighted Portfolio Returns (in percent) } \\
\hline \multirow[t]{2}{*}{$a$} & Coef & -0.184 & $-0.853^{* * * *}$ & -0.013 & $-0.701^{* * *}$ \\
\hline & $p$-val & 0.408 & 0.000 & 0.946 & 0.006 \\
\hline \multirow[t]{2}{*}{$b$} & Coef & $1.084^{* * *}$ & $1.136^{* * * *}$ & $1.091^{* * * *}$ & $1.111^{\text {****** }}$ \\
\hline & $p$-val & 0.000 & 0.000 & 0.000 & 0.000 \\
\hline \multirow[t]{2}{*}{$s$} & Coef & $1.259^{* * * *}$ & $1.254^{* * * *}$ & $1.307^{\text {**** }}$ & $1.335^{* * *}$ \\
\hline & $p$-val & 0.000 & 0.000 & 0.000 & 0.000 \\
\hline \multirow[t]{3}{*}{$h$} & Coef & $-0.283^{* * * *}$ & $-0.345^{* * * *}$ & $-0.328^{\text {***** }}$ & $-0.328^{* * *}$ \\
\hline & $p$-val & 0.006 & 0.001 & 0.002 & 0.005 \\
\hline & $\bar{R}^{2}$ & 0.842 & 0.849 & 0.875 & 0.818 \\
\hline \multirow{3}{*}{\multicolumn{2}{|c|}{$\begin{array}{l}a(\text { Aggressive })-a(\text { Conservative }) \\
t \text {-statistic } \\
\text { Two-tailed } P \text {-value }\end{array}$}} & \multicolumn{2}{|c|}{$-0.669^{* * * *}$} & \multicolumn{2}{|c|}{$-0.688^{\text {***** }}$} \\
\hline & & \multicolumn{2}{|c|}{-2.796} & \multicolumn{2}{|c|}{$\begin{array}{l}.000 \\
-3.087\end{array}$} \\
\hline & & \multicolumn{2}{|c|}{0.006} & \multicolumn{2}{|c|}{0.002} \\
\hline & $N$ & \multicolumn{4}{|c|}{156 months: January 1983-December 1995} \\
\hline
\end{tabular}

$* * *, * *, *$ denote significance at the 1,5 , and 10 percent levels, respectively. 
firms have very similar sizes, this selection ensures that size differences are small while discretionary accruals differences remain large between the two portfolios. The book-to-market adjustment is done similarly by first ranking all IPO firms by their issue year-end book-to-market ratios. ${ }^{19}$ The time series of equally weighted and value-weighted returns are calculated for each portfolio from January 1983 through December 1995 and the Fama-French three-factor model regression is estimated.

For each aggressive and conservative portfolio, the regression produces a single $t$-statistic on the estimated intercept that we use to test our hypothesis about the relation between DCA and post-issue stock return performance. Table IV indicates that the conservative DCA IPOs experience little underperformance while the aggressive DCA IPOs suffer significant postissue underperformance. The estimated intercept for the conservative DCA IPOs ranges from -0.184 percent to 0.078 percent per month, implying a range of -2.23 percent to +0.94 percent abnormal performance per year. The aggressive DCA IPOs have intercepts ranging from -0.853 percent to -0.554 percent per month, implying an underperformance range of 6.85 percent to 10.73 percent per year.

The estimated difference in intercepts between the conservative and aggressive portfolios and associated $t$-statistics is obtained from an unreported time-series regression of the difference in the returns between the conservative and aggressive portfolios on the factor returns. The estimated coefficients in these regressions range from -0.71 percent to -0.63 percent per month. These estimated coefficients imply abnormal trading profits ranging from 7.88 percent to 8.86 percent per year from a strategy of buying aggressive portfolio IPOs and shorting the conservative portfolio IPOs over the period when the IPOs remain in the respective portfolios. The $t$-statistics associated with these coefficients range from -1.7 to -3.1 , suggesting that aggressive IPOs have statistically significantly poorer post-issue performance than conservative IPOs. ${ }^{20}$

\section{Fama-MacBeth Panel Regressions}

The test specification in this subsection focuses on controlling for contemporaneous correlations in returns using the Fama and Macbeth (1973) monthly regressions. Moreover, we now use the firm's own size and book-to-market ratios, which are recommended by Daniel and Titman (1997) as better predictors of returns than the Fama-French factor return sensitivities. A final variation is that this regression allows us to compare the DCA influence on IPO firm returns against its influence on non-IPO firm returns.

\footnotetext{
19 The members of the aggressive and conservative portfolios in this section differ from those in earlier sections because here we control for size and book-to-market differences between portfolios.

20 The accruals effect increases if we truncate the sample at the 1st and 99th percentiles of DCA.
} 
One cross-sectional regression is run for each month, and overall statistics are calculated by averaging the time series of estimated coefficients and $t$-statistics. For each month, the returns (in percent) for all firms with appropriate data are regressed on lagged realizations of each firm's own four accrual variables, and the firm's own market-capitalization and book-tomarket ratio as control variables. We include an extra size control for smaller firms with equity capitalization of less than $\$ 100$ million.

Our sample includes all firms (with and without IPOs) that have sufficient CRSP and COMPUSTAT data to compute our variables. Additionally, firms must have a market capitalization entering the regression of at least $\$ 20$ million (in 1997 constant dollars), and a two-digit SIC code that places them in an industry in which there is at least one IPO firm in our sample. These criteria allow 2,472 firms to enter the March 1982 regression, and 4,230 firms to enter the February 1995 regression.

We run three sets of monthly cross-sectional regressions. The first set of regressions, termed " +6 to +17 mo" regressions, contains 168 monthly crosssectional regressions; the first of these regressions explains returns in March 1982, the last explains returns in February 1995. The independent variables are measured from financial statements closing six to seventeen months prior to the measured return. For example, the cross-sectional regression that explains returns in August 1985 uses accruals and other controls from the most recent financial statements that closed between March 1984 and February 1985. This same accounting information (for March 1984 to February 1985) is used in the "+ 18 to +29 mo" regression to explain August 1986 returns, and in the "+30 to +41 mo" regression to explain August 1987 returns. In sum, the first set of regressions uses independent variables from financial statements in the fiscal year which lag six to seventeen months behind the month of the dependent variable returns. The second set of regressions relates returns to accruals in the fiscal year which are lagged eighteen to twenty-nine months behind the returns. And the third set of regressions relates returns to accruals that are lagged thirty to forty-one months behind.

Each row in Table $\mathrm{V}$ summarizes the results of about fourteen years of regressions, with one coefficient and one $t$-statistic for each independent variable. We report the overall time-series average of these 168 crosssectional coefficients, and a $t$-statistic computed from the time-series of 168 individual month $t$-statistics which assumes only uncorrelatedness across months (but not unit-normality). ${ }^{21}$ Using the $t$-statistics to compute significance is more efficient than averaging the estimated coefficients; because

${ }^{21}$ More precisely, they are computed as $\mu\left(t_{m}\right) /\left[\sigma\left(t_{m}\right) / \sqrt{M-1}\right]$, where $t_{m}$ is the $t$-statistic in month $m$ and $M$ is the number of months (168 or 166). We also compute (but do not report) an overall $t$-statistic that assumes that each monthly $t$ is itself normally distributed with mean zero and unit variance, computed as $\sqrt{M-1} \cdot \mu\left(t_{m}\right)$. This restriction would raise the $t$-statistics on our coefficient. For example, in the twelve independent variable regressions, the $t$-statistic on DCA changes from -2.19 to -2.78 in the first row, from -0.80 to -1.03 in the second row, and from -1.88 to -2.78 in the third row. 


\section{Table V}

\section{Fama-MacBeth Panel Regressions}

The sample consists of 1,649 domestic IPO firms going public in the period from 1980 to 1992 with an offering price of at least $\$ 1$ and a market capitalization of $\$ 20$ million in 1997 prices (in year 0 ). Each row in Panel A summarizes the time-series coefficient averages (multiplied by 100) and $t$-statistics computed as $\mu\left(t_{m}\right) /\left[\sigma\left(t_{m}\right) / \sqrt{M-1}\right]$, where $t_{m}$ is the $t$-statistic in month $m$ and $M$ is the number of months (168 or 166) from Fama-MacBeth monthly cross-sectional regressions. Each row summarizes coefficients from 168 (166) months of cross-sectional regressions. In the first row, the " +6 to +17 mo" $(3 / 82-2 / 95)$ regressions, the dependent variable is the firm's raw return (in percent) in a given month (the first return is from 3/82, the last is from 2/95; to be included, a regression had to contain at least five IPO realizations). Independent variables are firm characteristics that are measured six to seventeen months earlier than each return month. The regressions contain 2,472 to 4,230 (average $=3,001.3$ ) observations per month). The second (third) row summarizes equivalent regressions, in which the independent variables are measured 18 to 29 (30 to 42) months before the stock return. The independent (accruals) variables in the "IPO Accruals" column are interacted with an issue dummy, i.e., they have nonzero values only if the relevant financial statement is the one immediately following the IPO. The boldfaced IDCA variable measures issue year (0) earnings management of discretionary current accruals. Table II and Appendix A describe the details of computing the four accruals measures. Book-to-market and market value act as controls for the Fama-French (1993) variables. Both IPO and non-IPO firms are excluded in years in which their lagged market value (an included independent variable) is less than $\$ 20$ million (in 1997 dollars), or when appropriate COMPUSTAT or CRSP information is unavailable. "Coef." is the average of the monthly regression coefficients, reported in percent (multiplied by 100). Panel B provides time-series statistics for independent variables entering the monthly regressions of the " +6 to +17 mo regressions," that is, gathered from the 168 monthly cross sections from $3 / 82$ to $2 / 95$. In each month, we compute a cross-sectional mean and standard deviation for both DCA and IDCA. This panel then reports a time-series mean and a timeseries standard deviation over these cross-sectional statistics. 
Panel A: Summary Statistics for Sets of 168 Monthly Cross-Sectional Regression Coefficients

\begin{tabular}{|c|c|c|c|c|c|c|c|c|c|c|c|c|c|}
\hline \multirow{2}{*}{$\begin{array}{c}\text { Offset } \\
\text { Months }\end{array}$} & & \multirow[b]{2}{*}{ Intercept } & \multirow{2}{*}{$\log \left(\frac{\mathrm{BV}}{\mathrm{MV}}\right)$} & \multirow[b]{2}{*}{$\log (\mathrm{MV})$} & \multirow{2}{*}{$\begin{array}{c}\log (\mathrm{MV}) \\
\text { if } \mathrm{MV}<100\end{array}$} & \multicolumn{4}{|c|}{ IPO Accruals } & \multicolumn{4}{|c|}{ All Accruals } \\
\hline & & & & & & IDCA & IDLA & INDCA & INDLA & DCA & DLA & NDCA & NDLA \\
\hline $\begin{array}{l}(+6 \text { to }+17 \mathrm{mo}) \\
(3 / 82-2 / 95)\end{array}$ & $\begin{array}{l}\text { Coef } \\
(t)\end{array}$ & $\begin{array}{c}0.784 \\
(0.15)\end{array}$ & $\begin{array}{l}0.168 \\
(6.85)\end{array}$ & $\begin{array}{l}0.068 \\
(2.30)\end{array}$ & $\begin{array}{l}-0.033 \\
(-1.13)\end{array}$ & $\begin{array}{l}-1.569 \\
(-4.12)\end{array}$ & $\begin{array}{l}3.331 \\
(2.35)\end{array}$ & $\begin{array}{l}-0.244 \\
(-0.46)\end{array}$ & $\begin{array}{l}2.276 \\
(1.42)\end{array}$ & & & & \\
\hline $\begin{array}{l}(+18 \text { to }+29 \mathrm{mo}) \\
(3 / 83-2 / 96)\end{array}$ & $\begin{array}{l}\text { Coef } \\
(t)\end{array}$ & $\begin{array}{l}1.199 \\
(1.13)\end{array}$ & $\begin{array}{c}0.109 \\
(4.71)\end{array}$ & $\begin{array}{c}0.035 \\
(1.58)\end{array}$ & $\begin{array}{l}-0.020 \\
(-0.92)\end{array}$ & $\begin{array}{l}-0.412 \\
(-1.96)\end{array}$ & $\begin{array}{l}5.778 \\
(2.53)\end{array}$ & $\begin{array}{r}2.239 \\
(-0.18)\end{array}$ & $\begin{array}{l}3.517 \\
(2.42)\end{array}$ & & & & \\
\hline $\begin{array}{l}(+30 \text { to }+41 \mathrm{mo}) \\
(3 / 84-12 / 96)\end{array}$ & $\begin{array}{l}\text { Coef } \\
(t)\end{array}$ & $\begin{array}{l}0.798 \\
(0.44)\end{array}$ & $\begin{array}{l}0.100 \\
(5.06)\end{array}$ & $\begin{array}{l}0.074 \\
(2.40)\end{array}$ & $\begin{array}{c}0.012 \\
(0.20)\end{array}$ & $\begin{array}{l}-2.836 \\
(-2.38)\end{array}$ & $\begin{array}{l}-3.536 \\
(-0.94)\end{array}$ & $\begin{array}{l}-1.481 \\
(-0.29)\end{array}$ & $\begin{array}{c}-1.344 \\
(0.11)\end{array}$ & & & & \\
\hline $\begin{array}{l}(+6 \text { to }+17 \mathrm{mo}) \\
(3 / 82-2 / 95)\end{array}$ & $\begin{array}{l}\text { Coef } \\
(t)\end{array}$ & $\begin{array}{l}0.856 \\
(0.29)\end{array}$ & $\begin{array}{c}0.161 \\
(6.89)\end{array}$ & $\begin{array}{c}0.069 \\
(2.32)\end{array}$ & $\begin{array}{l}-0.030 \\
(-1.00)\end{array}$ & $\begin{array}{l}-0.845 \\
(-2.19)\end{array}$ & $\begin{array}{c}2.921 \\
(1.98)\end{array}$ & $\begin{array}{c}0.115 \\
(0.05)\end{array}$ & $\begin{array}{l}1.500 \\
(0.91)\end{array}$ & $\begin{array}{l}-0.774 \\
(-5.09)\end{array}$ & $\begin{array}{l}0.723 \\
(2.65)\end{array}$ & $\begin{array}{l}-0.471 \\
(-2.01)\end{array}$ & $\begin{array}{l}1.228 \\
(2.14)\end{array}$ \\
\hline $\begin{array}{l}(+18 \text { to }+29 \mathrm{mo}) \\
(3 / 83-2 / 96)\end{array}$ & $\begin{array}{l}\text { Coef } \\
(t)\end{array}$ & $\begin{array}{l}1.268 \\
(1.30)\end{array}$ & $\begin{array}{r}0.107 \\
(4.81)\end{array}$ & $\begin{array}{l}0.032 \\
(1.49)\end{array}$ & $\begin{array}{l}-0.021 \\
(-0.95)\end{array}$ & $\begin{array}{r}0.042 \\
(-0.79)\end{array}$ & $\begin{array}{c}5.194 \\
(2.01)\end{array}$ & $\begin{array}{l}2.210 \\
(0.09)\end{array}$ & $\begin{array}{l}3.187 \\
(2.15)\end{array}$ & $\begin{array}{l}-0.501 \\
(-3.22)\end{array}$ & $\begin{array}{l}0.718 \\
(1.11)\end{array}$ & $\begin{array}{l}-0.086 \\
(-0.74)\end{array}$ & $\begin{array}{r}0.487 \\
(0.82)\end{array}$ \\
\hline $\begin{array}{l}(+30 \text { to }+41 \mathrm{mo}) \\
(3 / 84-12 / 96)\end{array}$ & $\begin{array}{l}\text { Coef } \\
(t)\end{array}$ & $\begin{array}{c}0.869 \\
(0.61)\end{array}$ & $\begin{array}{l}0.099 \\
(5.25)\end{array}$ & $\begin{array}{l}0.073 \\
(2.32)\end{array}$ & $\begin{array}{c}0.011 \\
(0.12)\end{array}$ & $\begin{array}{l}-2.699 \\
(-1.88)\end{array}$ & $\begin{array}{l}-3.800 \\
(-1.14)\end{array}$ & $\begin{array}{l}-1.531 \\
(-0.19)\end{array}$ & $\begin{array}{l}-1.762 \\
(-0.17)\end{array}$ & $\begin{array}{l}-0.148 \\
(-1.32)\end{array}$ & $\begin{array}{c}0.549 \\
(1.98)\end{array}$ & $\begin{array}{c}0.024 \\
(-0.12)\end{array}$ & $\begin{array}{c}0.894 \\
(1.63)\end{array}$ \\
\hline
\end{tabular}

Panel B: Univariate Statistics on DCA and IDCA Variables Entering the " +6 to $+17 \mathrm{mo"} \mathrm{Regressions} \mathrm{(in} \mathrm{percent)}$

\begin{tabular}{|c|c|c|c|}
\hline \multirow[b]{2}{*}{ Description } & \multicolumn{3}{|c|}{ Time-Series over 168 Numbers } \\
\hline & Mean & Std. Dev. & Range \\
\hline DCA Time-series over 168 cross-sectional averages & 1.94 & 0.82 & 0.2 to 4.0 \\
\hline DCA Time-series over 168 cross-sectional standard deviations & 33.73 & 25.18 & 12.5 to 119.9 \\
\hline IDCA Time-series over 168 cross-sectional averages & 0.37 & 0.26 & -0.1 to 1.0 \\
\hline IDCA Time-series over 168 cross-sectional standard deviations & 7.08 & 2.67 & 1.2 to 12.7 \\
\hline Time-series over 168 "percentage of nonzero IDCA" & 3.76 & & \\
\hline Among nonzero IDCAs in each month, IDCA time-series over 168 cross-sectional averages & 10.96 & 6.69 & -2.8 to 26.3 \\
\hline Among nonzero IDCAs in each month, IDCA time-series over 168 cross-sectional standard deviations & 36.40 & 6.88 & 23.3 to 54.5 \\
\hline
\end{tabular}


the early and late months with few observations are noisy and have low $t$-statistics, these are appropriately down-weighted..$^{22}$ We also impose an additional filter that at least five IPO firms must be available in a sample period because such months have undue influence on univariate means and standard deviations, and coefficient estimates (but not on the aggregated $t$-statistics). This filter disqualifies twelve months preceding the reported regressions.

Table V presents the results of these cross-sectional regressions. (Coefficients are quoted in percent.) IDCA is the accruals variable from the first post-IPO financial statement; this is zero for non-IPO accruals. It measures the influence of IPO accruals in explaining post-IPO accruals. Similarly, INDCA, IDLA, and INDLA measure the influence of other IPO accruals. The average monthly IDCA coefficient in the " +6 to $+17 \mathrm{mo"}$ regressions is -1.569 percent $(t=-4.1)$. As suggested by the time-series plot of abnormal returns (Figure 2), the IDCA coefficient is smaller in " +18 to $+29 \mathrm{mo"}$ regressions but larger in "+30 to $41 \mathrm{mo}$ " regressions. The average of the IDCA coefficients over the three post-IPO years is -1.61 percent $(=-(1.569+0.412+$ $2.836) / 3$ ). (Its three-year $t$-statistic is -4.88 assuming i.i.d. unit-normality.) To interpret the economic significance of this average coefficient, we make use of the univariate statistics in Panel B.

Averaging over the 3.76 percent of firm-return months that are issue months and so have nonzero IDCA, the average cross-sectional mean of IPO discretionary current accruals is 10.96 percent and its average crosssectional standard deviation is 36.4 percent. This indicates that 2.11 percent $(=1.61 \% \cdot 10.96 \% \cdot 12)$ of annual stock return underperformance can be attributed to an average level of earnings management in IPOs. As to performance differences across conservative versus aggressive issuers, the three-year average IDCA coefficient ( -1.61 percent) suggests that a one cross-sectional standard deviation in IDCA (36.4 percent) explains a -7.0 percent $(=1.61 \% \cdot 36.2 \% \cdot 12)$ annualized return differential.

The cross-sectional regressions in the bottom half of Panel A address whether the observed predictive power of IDCA for future returns is unique to IPOs or is also common to non-issue-related DCA. Firms in other periods, outside of the IPO event, may have other reasons to manage earnings, such as the avoidance of debt covenant constraints or regulatory restrictions, the payment of executive bonuses, or the issuance of seasoned equity (Teoh, Welch, and Wong (1998)). Sloan (1996) reports that total accruals can predict one-year-ahead returns in the population of COMPUSTAT firms (note that he does not separate accruals into discretionary and nondiscretionary components). We thus add a set of accrual variables, nonboldfaced, to denote accruals that are not IPO accruals (all accruals for non-IPO firms, and nonIPO period accruals for IPO firms). They measure whether accruals can predict future returns in the general population of firms. (General accrual

\footnotetext{
${ }^{22}$ Fama and MacBeth (1973) do not have this problem because their variables are not dummy variables and are equally available in all months.
} 
coefficients have smaller standard errors than IPO accrual coefficients because there are many more non-IPO than IPO firms.) The coefficients on the IPO-related boldfaced accrual variables now measure the incremental predictive ability of accruals to explain post-IPO returns, above and beyond what accruals can normally predict for all firms during non-IPO periods.

The estimated general DCA coefficients average to -0.47 percent over three years. The average discretionary current accruals population mean (1.94 percent) implies that average earnings management accounts for 0.11 percent $(=0.47 \% \cdot 1.94 \% \cdot 12)$ annual underperformance in the general population. But, although IPO accruals are larger (10.96 percent on average), the generic -0.47 percent DCA coefficient can explain only 0.62 percent $(=0.47 \% \cdot 10.96 \% \cdot 12)$ of the post-IPO annual return underperformance, a small amount of the rather large average post-IPO underperformance. A firm with a one cross-sectional standard deviation more aggressive earnings management measure (36.4 percent) underperforms by 2.05 percent per year $(=0.47 \% \cdot 36.4 \% \cdot 12)$ over the three following years, which is a respectable but not overwhelming return differential.

More important for us, the estimated coefficients suggest that only a small part of IDCA's ability to explain post-IPO returns comes from a general ability of DCA to explain post-IPO returns. When the non-issue-specific DCA variable is added, the three-year average IPO-specific IDCA coefficient changes from -1.61 percent (in the upper-half of Panel A) to -1.17 percent (in the lower half of Panel A), and remains statistically and economically significant.

Following the analysis above, the inclusion of non-IPO DCA accruals reduces the implied mean IPO-specific IDCA effect from 2.11 percent to 1.53 percent annualized return underperformance and reduces the implied one-standard cross-sectional deviation IDCA effect (i.e., the predicted return difference between conservative and aggressive issues) from a return underperformance of 7.0 percent to 5.1 percent per year. This 5 percent return differential per year is still relatively large and in line with our earlier estimates of economic significance. Note that when the IPO dummy equals one, approximately 29 percent of the predicted underperformance is attributable to the general DCA effect, and 71 percent to the IPO unique IDCA effect. This decomposition can be computed from the ratio of the IDCA and DCA coefficients. Said differently, the estimated coefficients ascribe more economic significance to the incremental IPO accruals influence on subsequent returns than to the general population accruals influence on subsequent returns.

Our paper is concerned with the three-year, not one-year, effect. The summed three-year total coefficient is always statistically significant. The weak DCA coefficients in the middle regressions are consistent with Figure 2, which illustrates only mild underperformance during post-event months 14 to 22 for even the aggressive quartile. The evidence suggests that our effect is strong in the first year immediately after the IPO, weak in the second year, and then picks up again strongly thereafter. (The coefficient and $t$-statistic 
are also negative if we lag one more year, i.e., 42 to 59 months.) The U-pattern in coefficients could be because of noise or because aggressive firms are discovered either very soon or much later after their IPO.

To conclude, we find that the earnings management variable is incrementally important during an initial public offering in explaining post-IPO longrun performance. ${ }^{23}$

\section{Post-Issuing Activity}

If our earnings management hypothesis is correct-that aggressive earnings management leads to poorer aftermarket performance as firms can no longer maintain appearances and must thus disappoint their investors-we would expect to see that conservative IPO accruers issue more seasoned equity offerings than aggressive IPO accruers, at least after the initial "deception" period. After all, issuers cannot borrow from future earnings to boost current earnings forever. The link between earnings management and post-issuing activity could be mechanical (in that aggressive earnings managers eventually earn such poor post-IPO returns that they are unable to raise capital in the SEO market), or it could be direct (in that aggressive earnings managers lose the trust of market participants). Both of these influences would be consistent with our hypothesis.

To test this hypothesis, we obtain a sample of seasoned equity offerings from SDC (1980-1997), and match (by CRSP IPERM) seasoned equity offerings to their corresponding IPOs. Equity offerings later than five years after the first post-IPO financial statements are excluded. Figure 3 displays the time-profile of seasoned equity offerings by post-issue quarter. For the 1,649 initial public offerings, we find 635 IPOs returning to issue 868 seasoned equity offerings. This frequency of SEOs after IPOs is similar to the rate reported in Welch (1989), even though we examine only firms with sufficient data to compute issue-year accruals. Issuing activity peaks about one year after the IPO for all quartiles (the highest slope in Figure 3). Of the 412 firms in each quartile (as defined in Table I), 170 of the conservative IPO issuers returned within five years with a total of 238 offerings. In contrast, only 152 of the aggressive IPO issuers returned for a total of 199 issues. Put another way, conservative issuers returned 20 percent more frequently than aggressive issuers to raise funds in a seasoned equity offering. This difference is large enough to be economically meaningful, although alone it is not large enough to serve as an earnings management deterrence for most IPO

\footnotetext{
${ }^{23}$ We also experiment with a "venture-capital" variable (VC) in our regression. SDC indicates that 41.4 percent of IPOs in our sample are venture-capital backed. These venture-capital backed IPOs are distributed evenly across the four quartiles from conservative quartile 1 to aggressive quartile 4 as follows: 27.1 percent, 23.7 percent, 24.6 percent, and 24.6 percent. Thus, VC-backed IPOs appear about as often in the conservative as in the aggressive quartiles. When VC-backing is added to the set of twelve independent variables, the coefficients on the VC dummy in the three yearly lags are 0.22 percent, 0.01 percent, and 0.36 percent, with $t$-statistics of $0.06,-0.45$, and 1.28 respectively. These small effects are inconsistent with Brav and Gompers (1997).
} 


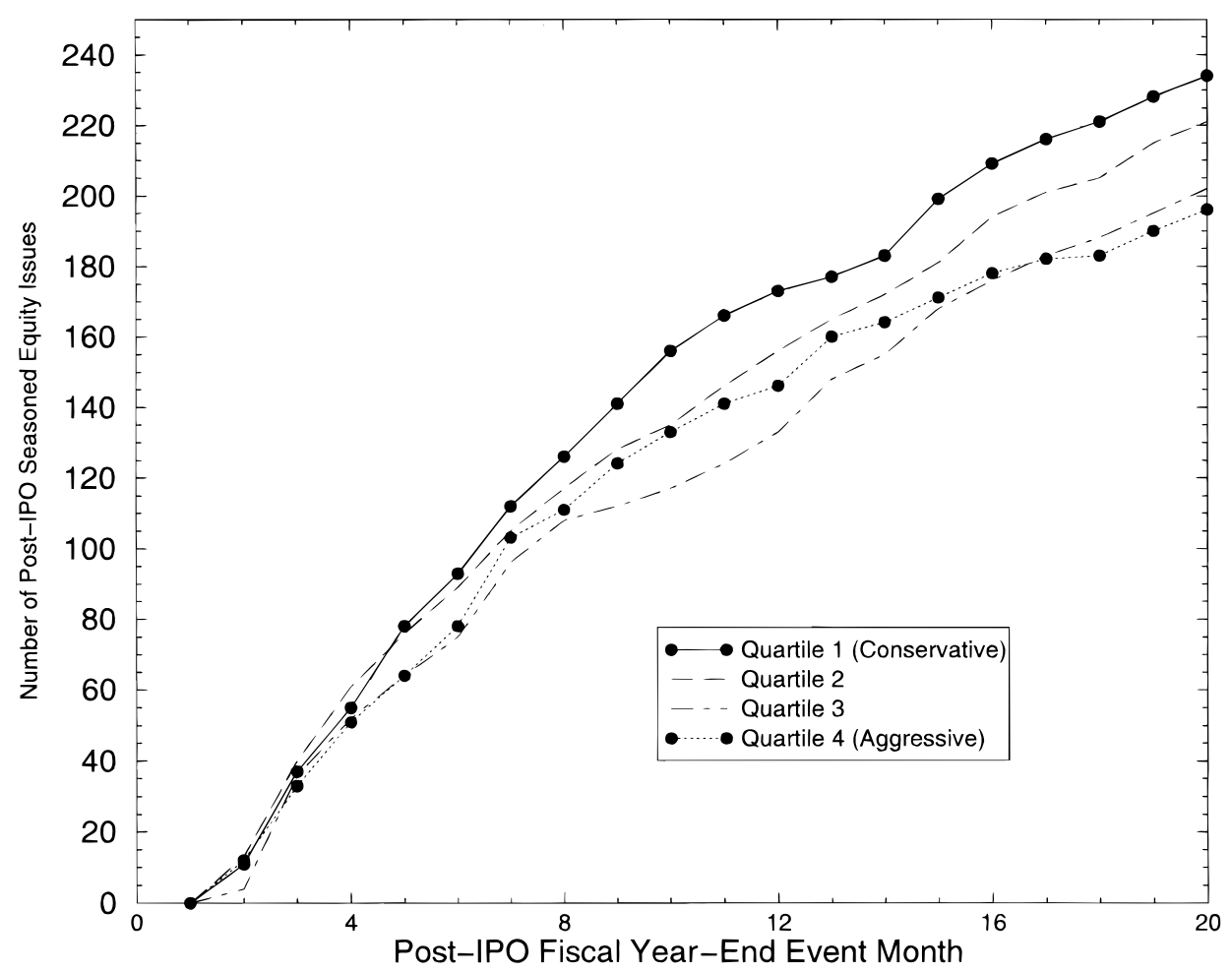

Figure 3. Cumulative seasoned equity offerings (SEOs) post-IPO by event month. The sample are 1,649 IPOs from the 1980-92 period. Details are described in Table I. Firms are divided into quartiles based on how aggressively they manage their earnings. Our measure of earnings management is firms' discretionary current accruals (DCA), which adjusts for industry, size, and growth. Details are described in Table II and Section I.B. The graph displays the total number of seasoned equity offerings by quarter relative to the first post-IPO financial statements.

firms. This evidence is also remarkable in light of the Welch (1989) signaling model, which explains IPO underpricing with the desire of high-quality firms to separate themselves. Jegadeesh, Weinstein, and Welch (1993) note that high IPO initial returns cannot easily be attributed to issuer choice because either issuers set a deliberately low offering price or because the market surprises issuers in its unexpectedly high post-IPO valuation of shares ("market feedback"). They attribute higher reissuing frequency of underpricing IPOs to market feedback. Our evidence here, however, examines a variable (earnings management) that is chosen by the issuer. If we equate "highquality issuers" with "conservative accruers," then our evidence suggests that higher quality issuers may indeed forgo pretending higher quality and may be rewarded by being able to reissue more frequently after the IPO. ${ }^{24}$

${ }^{24}$ This evidence does not imply that more conservative firms expect to return to the market with higher probability. They may simply respond to the post-IPO stock return performance. 


\section{Conclusion}

This paper examines the relation between the long-run post-IPO return underperformance and IPO firms' earnings management. We find that discretionary current accruals-which are under the control of management and proxy for earnings management-are high around the IPO relative to those of nonissuers. The paper documents that issuers with higher discretionary accruals have poorer stock return performance in the subsequent three years. A firm classified to be in the most aggressive quartile of IPO earnings managers experiences on average a 15 to 30 percent worse threeyear performance after its earnings report than a firm classified to be in the most conservative quartile. This result is robust with respect to the inclusion of other explanatory variables documented in the underperformance literature, to alternative test specifications, and to alternative abnormal returns measures. The IPO issuers in the conservative quartile also return to the capital market for a seasoned equity offering about 20 percent more frequently over a five-year period than those in the aggressive quartile, indicating a potential post-issue benefit to less-aggressive IPO earnings management. These results are consistent with an inability of investors to fully understand managerial earnings choices. Because investors behave as if they are fixated on these high earnings, they are disappointed later.

These findings have implications for investors, firms, and accounting standard setters. Investors may want to use information contained in the preoffering accounting accruals to discriminate among issuers. Entrepreneurs may want to consider how legitimate accounting choices can lower the firm's cost of equity capital or increase their own welfare. Finally, accounting standard setters may find these results useful for evaluating how much discretion they should allow corporate managers to adjust reported earnings.

\section{Appendix A: Calculation of Discretionary Accruals}

The four accrual variables in the paper are: discretionary current accruals (DCA), nondiscretionary current accruals (NDCA), discretionary long-term accruals (DLA), and nondiscretionary long-term accruals (NDLA). These four variables are components of total accruals AC, measured using COMPUSTAT annual item numbers in parentheses as follows:

$$
\mathrm{AC} \equiv \text { Net Income (172) - Cash Flows from Operations (308). }
$$

When cash flow from operations (308) is unavailable (prior to 1987), it is measured as funds flow from operations (110) minus current accruals CA. Current accruals are defined as the change in noncash current assets minus the change in operating current liabilities,

$$
\begin{aligned}
\mathrm{CA} \equiv & \Delta[\text { current assets }(4)-\operatorname{cash}(1)] \\
& -\Delta[\text { current liabilities (5) - current maturity of long-term debt (44)]. }
\end{aligned}
$$


Our paper follows the accounting literature in calculating current accruals as

$$
\begin{gathered}
\mathrm{CA} \equiv \Delta[\text { accounts receivables }(2)+\text { inventory }(3)+\text { other current assets }(68)] \\
-\Delta[\text { accounts payable }(70)+\text { tax payable }(71) \\
\quad+\text { other current liabilities }(72)],
\end{gathered}
$$

which reduces the influence of nonstandard classifications of certain items.

Nondiscretionary variables are expected accruals from a cross-sectional modification of the Jones (1991) model (see Teoh, Wong, and Rao (1998)) and the discretionary variables are the residuals. Expected current accruals for an IPO firm in a given year are estimated from a cross-sectional regression in that year of current accruals on the change in sales (12) using an estimation sample of all two-digit SIC code peers. (The IPO firm and other firms conducting an IPO or SEO firm in that year are not included in the regression.) Thus, for the expected current accruals of an IPO firm $i$ in year $t$, we run the following cross-sectional OLS regression:

$$
\frac{\mathrm{CA}_{j, t}}{\mathrm{TA}_{j, t-1}}=a_{0}\left(\frac{1}{\mathrm{TA}_{j, t-1}}\right)+a_{1}\left(\frac{\Delta \mathrm{Sales}_{j, t}}{\mathrm{TA}_{j, t-1}}\right)+\epsilon_{j, t}, \quad j \in \text { estimation sample }
$$

where $\Delta$ Sales is the change in sales, and TA is total assets (6). Nondiscretionary current accruals are calculated as

$$
\mathrm{NDCA}_{i, t} \equiv \hat{a}_{0}\left(\frac{1}{\mathrm{TA}_{i, t-1}}\right)+\hat{a}_{1}\left(\frac{\Delta \mathrm{Sales}_{i, t}-\Delta T R_{i, t}}{\mathrm{TA}_{i, t-1}}\right),
$$

where $\hat{a}_{0}$ is the estimated intercept and $\hat{a}_{1}$ is the slope coefficient for IPO firm $i$ in year $t$, and $\Delta T R_{i, t}$ is the change in trade receivables (151) in year $t$ for issuer $i$. We subtract the increase in trade receivables from change in sales to allow for the possibility of credit sales manipulation by the issuer (for example, by allowing generous credit policies to obtain high sales prior to the offering). See Teoh, Wong, and Rao (1998) for evaluation of the robustness of this measure relative to other measures. The results of our paper are robust to omitting this adjustment.

Discretionary current accruals, $\mathrm{DCA}_{\mathrm{i}, \mathrm{t}}$, for IPO firm $i$ for year $t$ are represented by the residual:

$$
\mathrm{DCA}_{i, t} \equiv \frac{\mathrm{CA}_{i, t}}{\mathrm{TA}_{i, t-1}}-\mathrm{NDCA}_{i, t}
$$

To obtain discretionary and nondiscretionary long-term accruals, discretionary and nondiscretionary total accruals are first estimated. The discretionary total accrual, $\mathrm{DAC}_{i, t}$, for IPO firm $i$ for year $t$ is calculated in a 
similar manner as for current accruals except that now total accruals $A C$ is used as the dependent variable and the regression includes gross property, plant, and equipment (PPE) as an additional explanatory variable.

$$
\begin{gathered}
\left(\frac{\mathrm{AC}_{j, t}}{\mathrm{TA}_{j, t-1}}\right)=b_{0}\left(\frac{1}{\mathrm{TA}_{j, t-1}}\right)+b_{1}\left(\frac{\Delta \text { Sales }_{j, t}}{\mathrm{TA}_{j, t-1}}\right)+b_{2}\left(\frac{\mathrm{PPE}_{j, t}}{\mathrm{TA}_{j, t-1}}\right)+\epsilon_{j, t}, \\
j \in \text { estimation sample. }
\end{gathered}
$$

Nondiscretionary total accruals or NDTAC are calculated as:

$$
\operatorname{NDTAC}_{i, t} \equiv \hat{b}_{0}\left(\frac{1}{\mathrm{TA}_{i, t-1}}\right)+\hat{b}_{1}\left(\frac{\Delta \mathrm{Sales}_{i, t}-\Delta T R_{i, t}}{\mathrm{TA}_{i, t-1}}\right)+\hat{b}_{2}\left(\frac{\mathrm{PPE}_{i, t}}{\mathrm{TA}_{i, t-1}}\right)
$$

where PPE is the gross property, plant, and equipment (7), $\hat{b}_{0}$ is the estimated intercept, and $\hat{b}_{1}$ and $\hat{b}_{2}$ are the estimated slope coefficients for IPO firm $i$ in year $t$. Thus, nondiscretionary long-term accrual is the difference between nondiscretionary total accrual and nondiscretionary current accrual. Finally, discretionary long-term accrual is the difference between assetscaled long-term accrual and nondiscretionary long-term accrual.

We emphasize discretionary current accruals, DCA as the key variable representing earnings management in the paper. Though discretionary longterm accruals also represent earnings management, managers have greater flexibility and control over current versus long-term accruals. The nondiscretionary components measure expected accrual responses to changes in firm business conditions, and so are not considered proxies of earnings management.

To illustrate the calculation of DCA, consider Integrated Waste Services Inc., ticker IWSI, CUSIP 457952, CRSP IPERM 76170, and SIC code 17. IWSI went public in May 1990 and its fiscal year 0 month was December 1990. The relevant accounting data items to compute DCA are shown in Table AI.

There were twenty-one firms in IWSI's two-digit SIC industry: Amelco (CUSIP 023438), Amre (032153), Apogee (037598), Canisco Resources (137587), Cerbco (156713), Diversified Communication (254919), Emcor Group (29084Q), Enviroq (293941), Gmx Communications (361911), Heist (423076), Insituform East (457662), Insituform Group (457663), Irex (462683), K D (482447), KDI (482452), MMR (553100), Metalclad (591142), Naylor (639349), Ryan Murphy (783508), TD (87299Y), and Williams (969493). Repeating the CA computations for these firms, and estimating the Jones model yields the fitted equation (see equation (A4))

$$
\frac{\mathrm{CA}_{j, t}}{\mathrm{TA}_{j, t-1}}=-0.014\left(\frac{1}{\mathrm{TA}_{j, t-1}}\right)+0.121\left(\frac{\Delta \operatorname{Sales}_{j, t}}{\mathrm{TA}_{j, t-1}}\right)+\epsilon_{j, t} .
$$


Table AI

Calculation of DCA

\begin{tabular}{lccr}
\hline & $\begin{array}{c}\text { Dec. 1990 } \\
\text { Year 0 }\end{array}$ & $\begin{array}{c}\text { Dec. 1989 } \\
\text { Year }-1\end{array}$ & \multicolumn{2}{c}{$\begin{array}{c}\text { Difference } \\
\Delta\end{array}$} \\
\hline Accounts receivable & 5.985 & 2.148 & 3.837 \\
Inventory & 0.091 & 0.000 & 0.091 \\
Other current assets & 0.721 & 0.241 & 0.480 \\
Accounts payable & 2.162 & 1.385 & 0.777 \\
Taxes payable & 0.329 & 0.455 & -0.126 \\
Other current liabilities & 0.728 & 0.920 & -0.192 \\
& & IPO Current Accruals (CA): & 3.949 \\
Trade receivable & 5.985 & 2.148 & 3.837 \\
Sales & 21.020 & 11.253 & 9.767 \\
Total assets & - & 20.375 & - \\
\hline
\end{tabular}

Equation (A6) gives IWSI's discretionary accruals as

$$
\begin{aligned}
\mathrm{DCA}_{i, t} & \equiv \frac{\mathrm{CA}_{i, t}}{\mathrm{TA}_{i, t-1}}-\mathrm{NDCA}_{i, t} \\
& =\frac{3.949}{20.375}-\left[\frac{-0.014}{20.375}+0.121\left(\frac{9.767-3.837}{20.375}\right)\right]=0.1593 .
\end{aligned}
$$

This places IWSI into accruals quartile 3, according to the quartile breakpoints in Table II.

\section{Appendix B: Methods of Earnings Management}

Accounting earnings that conform with GAAP can be manipulated because alternative treatments for accounting events are permitted. This section briefly discusses earnings management by choice of accounting methods, application of accounting methods, and timing of asset acquisitions and dispositions. ${ }^{25}$

1. Accounting Method Choice. The choice of accounting methods affects the timing of when revenues and expenses are recognized in income. Choices that advance the recognition of revenues and delay the recognition of expenses increase reported income. For example, the "percentage-completion method" permits recognizing revenues in ongoing projects, whereas the "completed-contract method" recognizes revenues only at completion. If input prices are falling, LIFO (last-infirst-out) costs of goods sold (based on later lower prices) are lower than FIFO (first-in-first-out) costs. For depreciable assets, straight-

${ }^{25}$ Earnings can also be managed by "real" decisions, such as timing and choice of investments, that have not only accounting but also economic implications. See Davidson, Stickney, and Weil (1986). 
line depreciation charges lower depreciation expenses more than accelerated depreciation in the initial periods.

2. Accounting Method Application/Discretionary Estimates. Even after the entrepreneur has chosen the accounting methods, there remains discretion in terms of how the accounting principles are applied. For example, the entrepreneur has discretion in the estimates of service lives and salvage values of depreciable assets, lives of intangibles, uncollectible rate on accounts receivable, cost of warranty plans, the degree of completion of long-term projects for revenue recognition, the actuarial cost basis for pension plan, and the interest rates for capitalized leases and for pension accounting.

3. Accounting Method Timing. The entrepreneur also has discretion over when and how events are recognized as accounting events requiring disclosure in the financial statements. For example, he has discretion over when and how much to write off bad loans and impaired assets, as well as over the estimates of market values in the application of the lower-of-cost-or-market method for inventory. He decides intent (longterm appreciation or short-term speculative classification) in the application of marked-to-market accounting for investments to affect the recognition of unrealized holding gains and losses. Furthermore, he decides how events are classified. For example, a liability may be recognized as contingent, even if it is almost certain, thus avoiding recognition of an expense in the income statement. He may also classify an indirect cost as a product cost rather than a period expense to avoid showing the expenditure as an expense in the income statement.

4. Timing. The timing of asset acquisitions and dispositions can affect accounting earnings as follows. The entrepreneur can choose when and how much to invest in $\mathrm{R} \& \mathrm{D}$, advertising, and maintenance costs, all three of which are recognized as expenses in the period when the costs are incurred. The entrepreneur also decides the timing of the sale of property, plant, and equipment to accelerate or delay recognition of gain or loss. The entrepreneur can accelerate or delay shipments of merchandise to customers at the end of a period to affect the timing of revenues. Finally, the entrepreneur's own compensation schedule can be altered to affect when compensation expenses are recognized in income.

The newsletter Financial Statement Alert, edited by Kellogg and Kellogg, reports suspicious examples of corporate earnings management, some of which may be fraudulent. The following summarizes some examples noted in Kellogg and Kellogg (1994, Part 3):

- Automatix overstated sales by including (1) shipments of equipment before providing necessary services and other equipment for customers to determine acceptance of product, (2) shipments to foreign subsidiaries before they were subsequently relayed to end customers, and (3) orders for goods to be shipped on trial.

- Alleghany International did not disclose facts about an unusual real estate sale. 
- American Express and Fireman's Fund swapped liabilities without transferring risks, and recorded premiums as income.

- Cannon Group failed to write down inventory.

- Cineplex Odeon Co. misclassified revenue items (gains and losses from asset sales are included in revenue from operations instead of other revenues), through choice of a fixed-costs amortization policy that allows for significant managerial discretion (fraction amortized depends on the manager's estimates of future revenues), mislabeling captions and misclassifying items (labeling bottom-line net income as income before extraordinary items, hiding related party transactions in other categories of revenues and accounts receivable, mislabeling cash flow from operations), inflating accounts receivables, and making inadequate provision for bad debts.

- Light Street Income Fund traded equity securities around ex dividend date, and bought and sold other securities at a loss in order to include dividend income as investment income and note capital loss, thereby inflating operating income (focus of analysts) without any effect on bottomline income.

- Marsh and McClellan failed to write down inventory, mark-to-market equity investments, and record a material loss. In addition, they overstated liabilities.

- Oak Industries smoothed earnings by establishing reserves, capitalized losses at start-up operations without proper establishment of reserves, refused to write down losses when appropriate, did not provide for losses on products that required further design work, and did not provide for losses and write-offs of uncollectible accounts receivable.

- Prime Motor Inns included related party transactions in operating results, inflated receivables with inadequate provision for losses, inadequately explained classification of asset categories, overstated revenues, inaccurately reported segment results, inadequately disclosed potential liabilities with third party transactions and related party transactions, and deferred writing down impaired assets.

- Savin Co. capitalized research and development expenditures instead of reporting them as expenses when incurred.

- Time Energy Systems reported management and incentive fee income and $\mathrm{R} \& \mathrm{D}$ income before providing services.

- Wespercorp recorded sales before assembly and shipment, used improper estimates of completion on long-term contracts, and unbundled hardware and software components to pick up sales on hardware shipments on long-term contracts.

\section{Appendix C: Further Book-to-Market and Firm-Size Controls}

Table CI cuts the sample into four categories based on book-to-market ratio, four categories based on equity capitalization, and sixteen crosscategories, and reports statistics on discretionary current accruals (DCA) and relevant market-adjusted buy-and-hold returns. The All column indi- 
Table CI

\section{Distribution of Discretionary Current Accruals Means, Three-Year Return Means, and their Correlations in Portfolios Classified by Size and Book-to-Market Quartiles.}

The sample here is as described in Table I except that we do not apply the $\$ 20$ million size cutoff. Firms are first grouped into four equal-numbered quartiles based on each firm's market value adjusted to December 1997 prices $\left(\mathrm{MV}^{*}\right)$ and into four equal-numbered quartiles based on each firm's book-to-market ratio. Based on these quartile ranks, we construct subgroups ("cells") categorized jointly by both the market value and book-to-market ratios (these subgroups have unequal numbers of firms). For each cell, we then report the mean of our earnings management variable $\left(\mu_{\mathrm{DCA}}\right)$, the three-year buy-and-hold returns net of the respective market index $\left(\mu_{\mathrm{BH}}\right)$, and the within-cell Pearson correlation $\left(\rho_{p r}\right)$ and Spearman correlation $\left(\rho_{s p}\right)$.

\begin{tabular}{|c|c|c|c|c|c|c|}
\hline & & $\begin{array}{c}\mathrm{B} / \mathrm{M} \\
\text { Ratio (Low) } \\
\text { up to } 0.23\end{array}$ & $\begin{array}{c}\text { B/M } \\
\text { Quartile 2 } \\
0.23-0.36\end{array}$ & $\begin{array}{c}\mathrm{B} / \mathrm{M} \\
\text { Quartile } 3 \\
0.36-0.55\end{array}$ & $\begin{array}{c}\mathrm{B} / \mathrm{M} \\
\text { Ratio (High) } \\
0.55 \text { and over }\end{array}$ & $\begin{array}{l}\text { All Firms } \\
\text { in Equity } \\
\text { Quartile }\end{array}$ \\
\hline \multirow{5}{*}{$\begin{array}{r}\mathrm{MV}^{*} \text { quartile } 1 \\
\text { (small firms) } \\
\text { up to } \$ 21.6 \mathrm{~m}\end{array}$} & $\mu_{\mathrm{DCA}}$ & 0.159 & 0.347 & 0.231 & 0.183 & 0.218 \\
\hline & $\mu_{\mathrm{BH}}$ & -0.546 & -0.395 & -0.236 & -0.236 & -0.319 \\
\hline & $\mathrm{N}$ & 98 & 88 & 139 & 212 & 537 \\
\hline & $\rho_{p r}$ & -0.141 & -0.02 & -0.044 & -0.129 & -0.61 \\
\hline & $\rho_{s p}$ & -0.037 & -0.149 & -0.114 & -0.167 & -0.054 \\
\hline \multirow{5}{*}{$\begin{array}{l}\mathrm{MV}^{*} \text { quartile } 2 \\
\quad \$ 21.7 \mathrm{~m}-\$ 58.3 \mathrm{~m}\end{array}$} & $\mu_{\mathrm{DCA}}$ & 0.357 & 0.135 & 0.108 & 0.108 & 0.162 \\
\hline & $\mu_{\mathrm{BH}}$ & -0.417 & -0.196 & -0.170 & -0.278 & -0.259 \\
\hline & $\mathrm{N}$ & 106 & 110 & 149 & 173 & 538 \\
\hline & $\rho_{p r}$ & -0.066 & -0.155 & 0.096 & 0.002 & -0.056 \\
\hline & $\rho_{s p}$ & -0.172 & -0.334 & -0.211 & -0.036 & -0.197 \\
\hline \multirow{5}{*}{$\begin{array}{l}\mathrm{MV}^{*} \text { quartile } 3 \\
\quad \$ 58.4 \mathrm{~m}-\$ 154.6 \mathrm{~m}\end{array}$} & $\mu_{\mathrm{DCA}}$ & 0.089 & 0.056 & 0.067 & 0.027 & 0.061 \\
\hline & $\mu_{\mathrm{BH}}$ & -0.229 & -0.075 & -0.135 & -0.028 & -0.114 \\
\hline & $\mathrm{N}$ & 104 & 194 & 151 & 89 & 538 \\
\hline & $\rho_{p r}$ & -0.089 & -0.069 & -0.055 & -0.030 & -0.068 \\
\hline & $\rho_{s p}$ & -0.206 & -0.127 & -0.032 & -0.085 & -0.118 \\
\hline \multirow{5}{*}{$\begin{array}{c}\mathrm{MV}^{*} \text { quartile } 4 \\
\quad \text { (large firms) } \\
\quad \text { over } \$ 154.7 \mathrm{~m}\end{array}$} & $\mu_{\mathrm{DCA}}$ & 0.065 & 0.064 & 0.068 & 0.046 & 0.063 \\
\hline & $\mu_{\mathrm{BH}}$ & -0.003 & -0.127 & -0.087 & -0.117 & -0.034 \\
\hline & $\mathrm{N}$ & 229 & 146 & 99 & 64 & 538 \\
\hline & $\rho_{p r}$ & -0.051 & -0.092 & -0.051 & -0.187 & -0.048 \\
\hline & $\rho_{s p}$ & -0.096 & -0.209 & -0.069 & -0.241 & -0.111 \\
\hline \multirow{5}{*}{$\begin{array}{l}\text { All firms in } \\
\text { B/M quartile }\end{array}$} & $\mu_{\mathrm{DCA}}$ & 0.145 & 0.122 & 0.121 & 0.117 & 0.123 \\
\hline & $\mu_{\mathrm{BH}}$ & -0.228 & -0.166 & -0.130 & -0.202 & -0.181 \\
\hline & $\mathrm{N}$ & 537 & 538 & 538 & 538 & 2151 \\
\hline & $\rho_{p r}$ & -0.086 & -0.072 & -0.013 & -0.086 & -0.065 \\
\hline & $\rho_{s p}$ & -0.164 & -0.150 & -0.118 & -0.136 & -0.141 \\
\hline
\end{tabular}

cates that stock return underperformance monotonically decreases with firm size, but there is no apparent relation in the $A l l$ row-that is, within bookto-market quartiles. The overall Pearson correlation of -0.065 and Spearman correlation of -0.141 are both significant at less than the 1 percent level. The table shows that the predictive ability of DCA is not driven by a small number of firms with certain firm size and book-to-market characteristics only. The accruals influence patterns are also observed looking within the cells. Thus, our findings differ from those in Brav and Gompers (1997) in that we do not find underperformance or the accruals effect isolated within 
the small size and book-to-market cells only. Our earnings management variable, DCA, shows some systematic relation with size (larger for the two smallest-sized quartiles) but not with book-to-market. (It is not distinctly different across book-to-market quartiles.) A strong correlation between returns and accruals is present in many of the sixteen cells and there is no apparent systematic pattern of where they are present. Thus, our DCA variable is unlikely to be just a proxy for small size and low book-to-market. We are fairly confident that our test specifications and controls allow us to test the incremental influence of accruals in predicting post-issue returns without significant contamination by size or book-to-market.

\section{REFERENCES}

Ali, Ashiq, 1996, Bias in analysts' earnings forecasts as an explanation for the long-run underperformance of stocks following equity offerings, Working paper, University of Arizona.

Barber, Brad M., and John Lyon, 1997, Detecting long-run abnormal stock returns: The empirical power and specification of test statistics, Journal of Financial Economics 43, 341-372

Brav, Alon, and Paul A. Gompers, 1997, Myth or reality? The long-run underperformance of initial public offerings: Evidence from venture and nonventure capital-backed companies, Journal of Finance 52, 1791-1821

Buser, Stephen A., and K. C. Chan, 1987, Nasdaq/NMS Qualification Standards, Ohio Registration Experience and the Price Performance of Initial Public Offerings, (Columbus, Ohio, Department of Commerce and National Association of Securities Dealers, Inc.).

Cheng, Li-Lan, 1995, Equity issue underperformance and the timing of security issues, Working paper, Massachusetts Institute of Technology.

Daniel, Kent, and Sheridan Titman, 1997, Evidence on the characteristics of cross sectional variation in stock returns, Journal of Finance 52, 1-33.

Davidson, Sidney, Clyde Stickney, and Roman Weil, 1986, Accounting: The Language of Business (Thomas Horton and Daughters, Sun Lakes, Arizona).

Dechow, Patricia, Amy Hutton, and Richard Sloan, 1997, The relation between analysts' longterm earnings forecasts and stock price performance following equity offerings, Working paper, University of Michigan.

Degeorge, Francois, and Richard Zeckhauser, 1993, The reverse LBO decision and firm performance: Theory and evidence, Journal of Finance 48, 1323-1348.

Fama, Eugene F., 1998, Market efficiency, long-term returns, and behavioral finance, Journal of Financial Economics, forthcoming.

Fama, Eugene F., and Kenneth R. French, 1993, Common risk factors in the returns on stocks and bonds, Journal of Financial Economics 33, 3-56.

Fama, Eugene F., and James MacBeth, 1973, Risk, return and equilibrium: Empirical tests, Journal of Political Economy 81, 607-636.

Field, Laura, 1995, Is institutional investment in initial public offerings related to long-run performance of these firms?, Working paper, University of California, Los Angeles.

Guenther, David A., 1994, Earnings management in response to corporate tax rate changes: Evidence from the 1986 tax reform act, Accounting Review 69, 230-243.

Ibbotson, Roger G., 1975, Price performance of common stock new issues, Journal of Financial Economics 2, 235-272.

Jain, Bharat, and Omesh Kini, 1994, The post-issue operating performance of IPO firms, Journal of Finance 49, 1699-1726.

Jegadeesh, Narasimhan, Mark Weinstein, and Ivo Welch, 1993, IPO signaling and subsequent equity offerings: An empirical investigation, Journal of Financial Economics 34, 153-176.

Jones, Jennifer, 1991, Earnings management during import relief investigation, Journal of Accounting Research 29, 193-228.

Kellogg, Irving, and Loren Kellogg, 1994, Fraud, Window Dressing, and Negligence in Financial Statements (Shepard's Commercial Law Series), McGraw-Hill Inc. 
Kim, Moonchul, and Jay Ritter, 1998, Valuing IPOs, Working paper, University of Florida.

Lin, Hsou-wei, and Maureen McNichols, 1997, Underwriting relationships and analysts' research reports, Working paper, Stanford University.

Loughran, Tim, and Jay Ritter, 1995, The new issues puzzle, Journal of Finance 50-1, 23-51.

Lyon, John D., Brad M. Barber, and Chih-Ling Tsai, 1998, Improved methods for tests of longrun abnormal stock returns, Journal of Finance, forthcoming.

Michaely, Roni, and Kent Womack, 1996, Conflict of interest and the credibility of underwriter analysts recommendations, Working paper, Cornell University.

Mikkelson, Wayne, Megan Partch, and Ken Shah, 1997, Ownership and operating performance of companies that go public, Journal of Financial Economics 44, 281-307.

Rajan, Raghuram, and Henri Servaes, 1997, Analyst following of initial public offerings, Journal of Finance 52, 507-529.

Rao, Gita R., 1993, The relation between stock returns and earnings: A study of newly-public firms, Working paper, Kidder Peabody and Co., New York.

Ritter, Jay, 1991, The long-run performance of initial public offerings, Journal of Finance 46, $3-27$.

Sloan, Richard, 1996, Do stock prices fully impound information in accruals about future earnings?, Accounting Review 71, 289-315.

Stern, Richard, and Paul Borstein, 1985, Why new issues are lousy investments, Forbes 136, $159-190$.

Stoll, Hans, and Anthony Curley, 1970, Small business and the new issues market for equities, Journal of Financial and Quantitative Analysis 5, 309-322.

Teoh, Siew Hong, Ivo Welch, and T. J. Wong, 1998, Earnings management and the post-issue underperformance in seasoned equity offerings, Journal of Financial Economics 50, 63-99.

Teoh, Siew Hong, and T. J. Wong, 1998, Analysts' credulity about reported earnings and the overoptimism in new equity issues, Review of Financial Studies, forthcoming.

Teoh, Siew Hong, T. J. Wong, and Gita R. Rao, 1998, Are earnings during initial public offerings opportunistic?, Review of Accounting Studies, forthcoming.

Welch, Ivo, 1989, Seasoned offerings, imitation costs, and the underpricing of initial public offerings, Journal of Finance 44, 421-449.

Welch, Ivo, 1997, G-III Apparel Group Inc, Case study, University of California, Los Angeles. 